\title{
Impact of Climate Change on Groundwater Recharge in Cotton Irrigated Fields under Agronomical Practices
}

\section{Muhammad Saeed}

University of Agriculture Faisalabad

Ahsan Maqbool ( $\sim$ ahsanksr@hotmail.com )

Spanish National Research Council https://orcid.org/0000-0002-5968-3390

\section{Muhammad Adnan Ashraf}

University of Agriculture Faisalabad

Muhammad Arshad

University of Agriculture Faisalabad

\section{Kashif Mahmood}

University of Bonn: Rheinische Friedrich-Wilhelms-Universitat Bonn

\section{Muhammad Usman}

Martin Luther University Halle Wittenberg: Martin-Luther-Universitat Halle-Wittenberg

\section{Muhammad Arslan Farid}

University of Agriculture Faisalabad

\section{Research Article}

Keywords: Groundwater, Recharge flux, Climate Change, Hydrus-1D, Cotton.

Posted Date: August 31st, 2021

DOl: https://doi.org/10.21203/rs.3.rs-729316/v1

License: (c) (i) This work is licensed under a Creative Commons Attribution 4.0 International License. Read Full License 

Irrigated Fields under Agronomical Practices

3 Muhammad Saeed $^{1 \dagger}$, Ahsan Maqbool ${ }^{2 \dagger *}$, Muhammad Adnan Ashraf ${ }^{1}$, Muhammad Arshad ${ }^{1}$, Kashif

4 Mahmood $^{1,3}$, Muhammad Usman ${ }^{4}$, Muhammad Arslan Farid ${ }^{1}$

$5 \quad{ }^{1}$ Department of Irrigation and Drainage, University of Agriculture Faisalabad, 38000 Pakistan.

$6{ }^{2}$ Institute for Sustainable Agriculture, Spanish National Research Council, Cordoba, 14001, Spain.

$7 \quad{ }^{3}$ Center for Development Research (ZEF), University of Bonn, 53113 Bonn, Germany.

$8{ }^{4}$ Department of Geoecology, Institute of Geosciences and Geography, University of Halle-Wittenberg, 906120 Halle (Saale), Germany.

$10 \dagger$ These authors contribute equally to this work.

$11 *$ *Corresponding author: ahsanksr@hotmail.com

12 


\section{ABSTRACT}

Cotton crop is one of the major water consumers in the Indus basin region. Accurate

15 groundwater recharge estimation is a provoking duty due to hydrologic and environmental applications under climate change in the agricultural sector. An utmost region that is vulnerable to

17 climate change and cotton production is declining, consequently. Here, historical trends (19752005) and future variability (2021-50 and 2051-80) of climate parameters were analyzed and predicted by SDSM for three emission scenarios (RCP 2.6, RCP 4.5, and RCP 8.5) for the semiarid region Faisalabad, Pakistan. Results revealed a rise in maximum (minimum) temperature and

21 a decline in rainfall, relative humidity, and wind speed for both 2021-50 and 2051-80 using

22 different NCEP parameters $(p<0.05)$. The groundwater recharge was simulated using the Hydrus-

23 1D unsaturated flow model. Hydrus-1D unsaturated flow model simulated the groundwater

24 recharge under six treatments. A $41 \mathrm{~cm}$ reduction of groundwater recharge was observed under all 25 scenarios. The highest recharge was observed $71 \mathrm{~cm}$ under RCP 2.6, and the lowest recharge was $2630 \mathrm{~cm}$ under RCP 8.5, a maximum of $23 \%$ groundwater recharge controlled by climate variables 27 with the weak relationship among them. Cotton sowing method $\mathrm{T}_{6}$ (bed planting without mulch)

28 showed the highest yield $\left(1,066 \mathrm{~kg} \cdot \mathrm{ha}^{-1}\right)$. It further indicates that rather than climate change, the 29 agronomical practice may have a more significant impact on groundwater recharge and cotton yield. Findings highlight the significance of both climate change and the cotton sowing method

31 while accessing future water resources in irrigated Indus basin agriculture.

32 Keywords: Groundwater, Recharge flux, Climate Change, Hydrus-1D, Cotton. 


\section{INTRODUCTION}

Global cotton production requires 250 billion tons of water annually. In most developed countries, like Japan 95\%, European Union 84\%, and the United States over 50\% water footprint from cotton consumption is cross-border, with impacts highest in Pakistan, India, China, and

37 Uzbekistan. Pakistan is the fourth producer of cotton globally (Abbas 2020), the third-largest exporter of raw cotton, contributing up to $10 \%$ of GDP. Among top countries most vulnerable to climate change and most intensively cultivated region on Earth (Vinca et al. 2020). The production and annual growth rate of Pakistan cotton are presented in Fig. 1 based on historical data since 1960. One significant reason for the long-term decline in Pakistan's cotton production is climate change and the non-availability of quality seeds (Rehman 2021). Cotton crop cultivated in arid to semiarid (Punjab and Sindh province under Indus Delta) is more sensitive to climate risk (Abbas 2020). Rising temperature is not only decreasing Pakistan's cotton yield while also exerting additional stress on water demands for the agricultural (cotton) and socio-economic sectors in the agro-ecological zone (Naheed and Rasul 2005; Abbas 2020; Saleem et al. 2021). Meanwhile, in a semiarid or arid region for the agricultural sector, groundwater plugs the gaps of crop water requirement or canal (allocated) water supplies, has caused a lowering of depth to the water table from 10 to $25 \mathrm{~m}$ (Khan et al. 2017; Maqbool et al. 2021). That leads to adopting mitigation techniques to increase water conservation for cotton's environmentally friendly production. It is

51 significant to access the groundwater recharge under future climate change in an irrigated cotton

52 field to sustain natural resources for rural socio-economic development for a consistent cotton 53 growth rate (Fig.1).

Groundwater recharge is water that crosses or punctuates the aquifer from surface or 55 subsurface water ponding via terrestrial infiltration, leading to a bouncy source of freshwater 
56 (Anderson et al., 2015). Accurate estimation of groundwater recharge is one of provoking duties

57 due to hydrologic and environmental applications, influenced by several factors such as stochastic

58 characteristics of rainfall, climatic parameters, and strata's infiltration capacity. It is interactively

59 inflated by evapotranspiration, natural vegetation and crop patterns, flood frequency, and soil

60 organic matter, particularly in agricultural problems, and their vulnerability is attributed to climate

61 change (Şen 2015; Boughanmi et al. 2018; Wakode et al. 2018). Agriculture has a substantial

62 impact on groundwater recharge quality and quantity, with the input of irrigation and fertilizer that

63 may alter groundwater recharge fluxes and mobility of salts/pollutants from unsaturated zone to

64 groundwater (Turkeltaub et al. 2014). Insufficient groundwater abstraction has waterlogged the

65 land that creates a salinity problem (Maqbool et al. 2021); contrary, excessive pumpage has caused

66 depletion of groundwater resources in a semi-arid agricultural region (Khaliq et al. 2021). The

67 sustainability of water resources depends on evaluating water footprint accounting in irrigated

68 fields (Xu and Li 2020). Previously found, groundwater recharge is very sensitive to potential

69 future climate changes (Ficklin et al. 2010; Turkeltaub et al. 2014; Batalha et al. 2018). Increasing

70 temperature $\left(5.7^{\circ} \mathrm{C}\right.$ annually by the late 21 st century) and declining rainfall $(11.9 \%$ in the mid-

71 21st century) were reported (Dahri et al. 2021). Erratic climate change exploits groundwater

72 recharge estimation and could create hyper stress on groundwater recharge under the irrigated 73 agricultural field. 


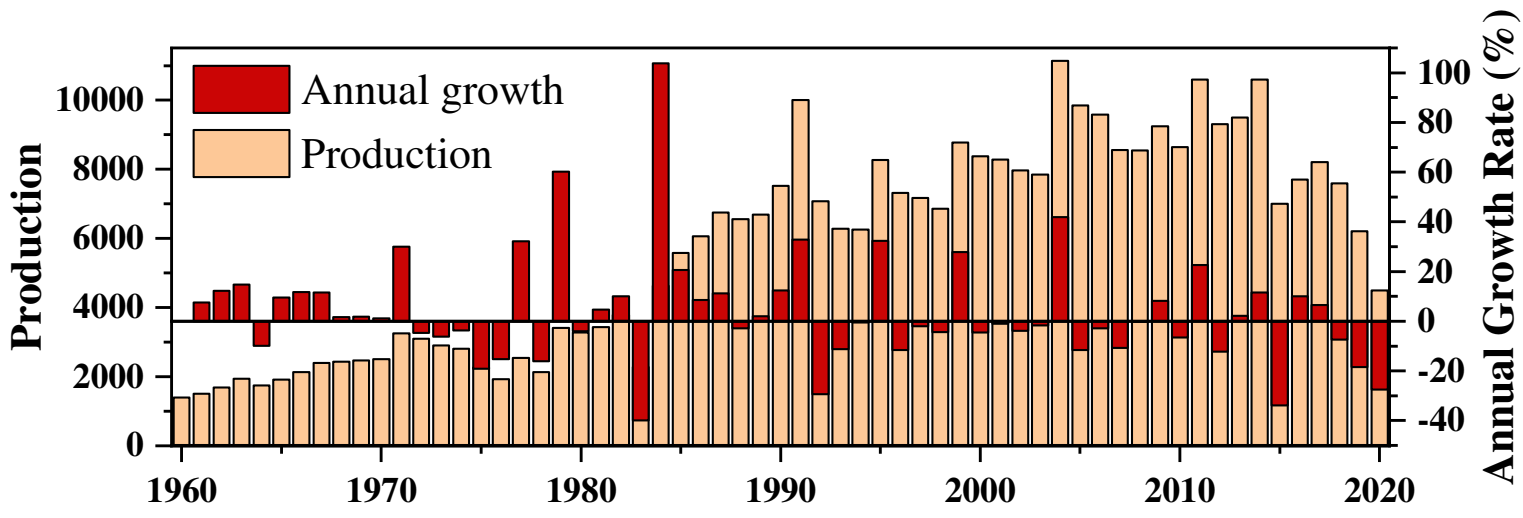

Figure 1: cotton annual growth rate (\%) and production (1000 $480 \mathrm{lb}$. Bales) in Pakistan from 1960 to 2020. Source: www.indexmundi.com

Crop models and hydrologic models can access water variability in agro-hydrologic development themes for groundwater recharge (Siad et al. 2019). Hydrologic models are emphasized more due to continuous and mechanistic processes of soil water movement (Tenreiro et al. 2020). HYDRUS-1D can simulate the solute movement in the vadose zone and recharge flux below the root zone (Šimůnek et al. 2013). Turkeltaub et al. (2014) used HYDRUS-1D to develop a vertical unsaturated flow model and reported a $44 \%$ drop in groundwater recharge under agricultural (orchard and crop) fields following climate change scenarios. Increased daily temperatures from 1.1 to $6.4{ }^{\circ} \mathrm{C}$ can decrease the cumulative groundwater recharge due to reduced water use efficiency by the crops (Ficklin et al. 2010). Kambale et al. (2017) simulated the groundwater recharge by HYDRUS-1D in the semiarid region (northern India) reported that recharge flux would decrease by .0 .090 to $.0 .210 \mathrm{~m}$ under Inter-Governmental Panel for Climate Change (IPCC) and.0.110 m under Indian Network for Climate Change Assessment (INCCA) for projected temperatures 2100s and 2030s, respectively. Meanwhile, the HYDRUS-1D model could provide better insight into groundwater recharge simulation, including capillary rise, hysteresis, preferential flow, subsurface lateral flow, and surface outflow for spatial water processes (vadose 
92 zone process or data) (Tenreiro et al. 2020). Besides, statistical downscale modeling (SDMS) is a

93 reliable decision support tool to generate future climatic parameters based on historical trends for

94 a potential climate-driven impact assessment on groundwater recharge (Azam et al. 2020; Wu et

95 al. 2020).

Trends and variability of groundwater recharge in the agricultural sector of Pakistan remain

97 unidentified under future climate change. A series of studies relating to groundwater recharge is available under changing climate scenarios considering only a temperature rise (Kambale et al.

99 2017; Rahman et al. 2019; Wu et al. 2020). Nevertheless, some studies have described quantifying the impact of climate change on groundwater recharge by considering unsaturated zone processes.

101 It is important to look at an irrigated cotton field because climate change is not homogenous across 102 the Indus Basin region and different strategies need to adopt for increasing cotton yield and water 103 use efficiency to mitigate their impact. The current study addresses this knowledge gap by 104 investigating the groundwater recharge in an irrigated cotton field in a semi-arid area of Pakistan.

In this paper, first, historical trend analysis from 1975 to 2005 of climate parameters, i.e., 106 minimum and maximum temperature, rainfall, relative humidity, and wind speed by SDMS and 107 predicted their variability for future 2021-2050 and 2051-80 under representative concentration 108 pathway (RCP) 2.6, RCP 4.5, and RCP 8.5, respectively. Secondly, to simulate groundwater 109 recharge from irrigated cotton fields using numerical unsaturated flow modeling under different 110 agronomical practices with or without mulch. Thirdly, perform the regression and correlation 111 analysis to evaluate the relationship between groundwater recharge and climate variables. Lastly, 112 different agronomical practices also accessed the cotton yield. 


\section{Study area}

115 The study was conducted under a cotton (Gossypium) field, located in Rechna doab upland of 116 Punjab at Water Management Research Center (WMRC), Faisalabad $\left(31.3872^{\circ} \mathrm{N}\right.$ latitude and $11773.0121^{\circ}$ E longitude, Fig. 1). Semi-arid climate in Köppen-Geiger classification of this area, with 118 very hot and humid summers (April-October) and dry, cool winters (November-March). The 119 maximum temperature in the hottest month is $50^{\circ} \mathrm{C}$ (June), and the minimum temperature in the 120 coldest month is $8^{\circ} \mathrm{C}$ (December), an altitude of $184 \mathrm{~m}$ above mean sea level based on the nearest 121 (under 2-km of research site) station's data provided by National Institute for Agriculture and 122 Biology (NIAB), Faisalabad and. The average rainfall in the area is $283 \mathrm{~mm}$, and the maximum 123 rainfall event occurred during July. Study area falls in a mixed cropping zone of the Punjab Agro124 Ecological zone, including wheat, rice, cotton, sugarcane, and maize are to be grown (AMIS 2016). 125 Cropping intensity of the Faisalabad district now reaches $\sim 150 \%$ due to the high demands of food 126 (edible) crops. The study area part of the Indus plain that comes under the area has fertile land due 127 to the alluvial soil genesis of Chenab Delta. The soil type is medium texture and homogenous 128 structure up to $4 \mathrm{~m}$ depth. This plain is underlain by thick sandy loam to loamy sand with high 129 hydraulic conductivity (Kelleners et al. 1999). According to the soil survey of Pakistan, the site's 130 soil has low organic matter and $\mathrm{pH}(7.0$ - 7.9), which is feasible for various crops. 


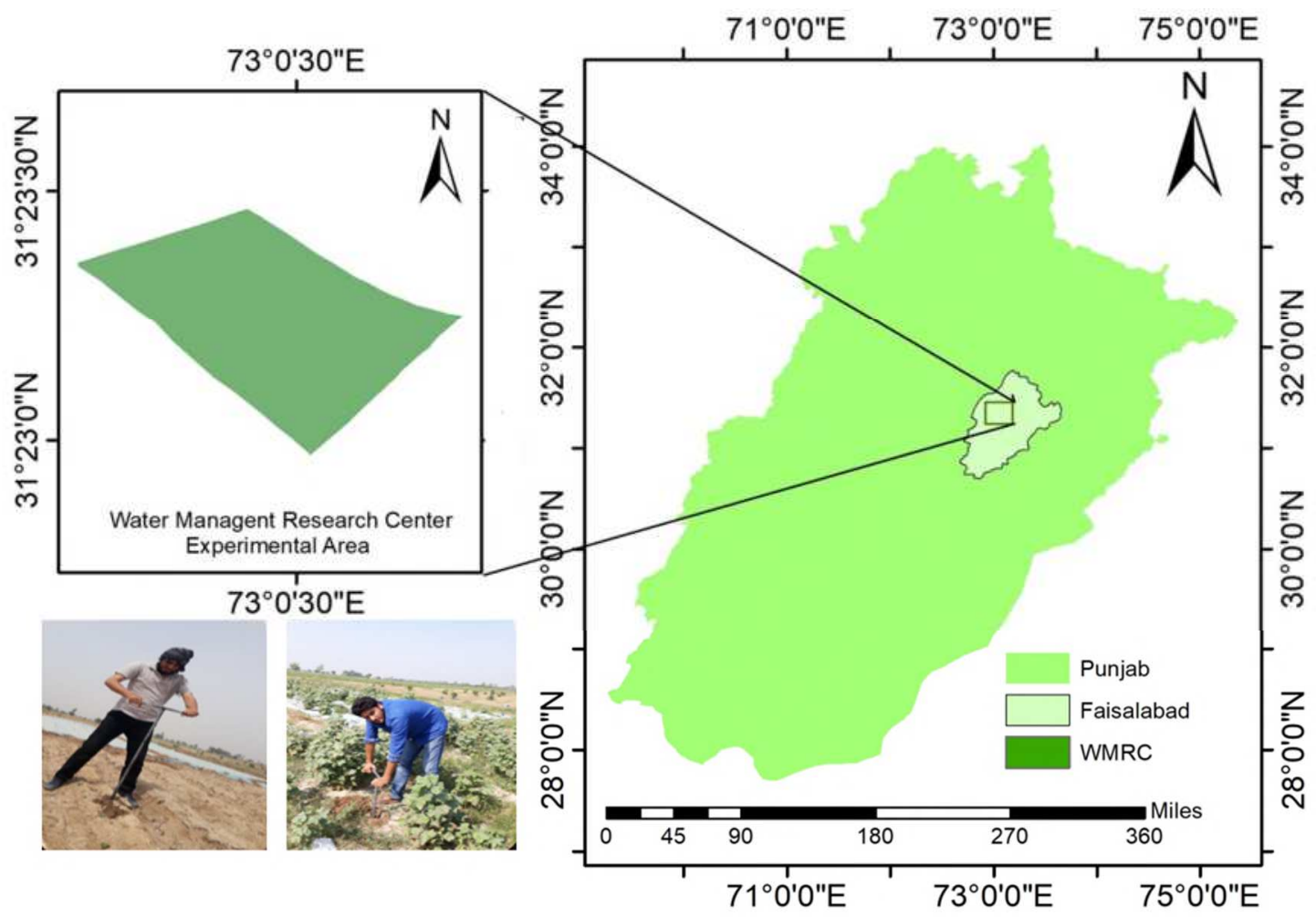

131

132 Figure-2: Cotton irrigated crop sampling sites at Water Management Research Center (WMRC),

Faisalabad. 


\section{Experimental setup and data collection}

The experiment was conducted by Randomized Complete Block Design (RCBD), the sowing method, and land cover. The three sowing methods were studies, i.e., flat sowing, ridge sowing, and bed sowing with mulch and non- mulch land cover. There were six treatments, i.e., $\mathrm{T}_{1}$ (flat sowing with mulch), $\mathrm{T}_{2}$ (flat sowing without mulch), $\mathrm{T}_{3}$ (ridge sowing with mulch), $\mathrm{T}_{4}$ (ridge sowing without mulch), $\mathrm{T}_{5}$ (bed planting with mulch), and $\mathrm{T}_{6}$ (bed planting without mulch), respectively with three repetitions. The plot size was $6 \mathrm{~m} \times 4.5 \mathrm{~m}$, and the total experimental area was about 0.141 ha. The cotton crop was sown on June 13, 2017, and harvested on November 20, 2017, with three replication of each treatment. Therefore, the total simulation period for groundwater recharge flux was 150 days.

Moisture content data was collected from the fields at seven-day intervals. The soil sampling was done at 0-30 cm, 30-60 cm, and 60-90 $\mathrm{cm}$ depth from each treatment plot with a fixed interval-soil sample collected by a vertical borehole (auger-hole) drilling method (Fig. 2).

The moisture content of the soil sample was measured using the oven-dry method for 24 hours at $105^{\circ} \mathrm{C}$. Gravimetric moisture content $\left(\theta_{\mathrm{g}}\right)$ was obtained, and volumetric moisture content $\left(\theta_{\mathrm{v}}\right)$ calculated by $\theta_{\mathrm{v}}=\theta_{\mathrm{g}} \times$ apparent specific gravity. Meanwhile, apparent specific gravity is the ratio of $\rho_{s}=$ bulk density of soil $\left(\mathrm{g} / \mathrm{cm}^{3}\right)$; and $\rho_{w}=$ bulk density of water $\left(\mathrm{g} / \mathrm{cm}^{3}\right)$.

The irrigation water was applied as a rotational program followed by the Extension and Adaptive Research Wing of the Punjab Agriculture Department. Detailed rotational methods can be found elsewhere (Maqbool et al. 2021). The department has fixed the irrigation interval based on the sowing method; the irrigation interval is seven days for bed and ridge sowing and flat sowing ten days of the cotton crop. Irrigation depth was calculated by following expression QT = 
$156 \mathrm{AD}$, where $\mathrm{Q}=$ discharge of the outlet/ tubewell (cusec); $\mathrm{T}=$ time of irrigation (hour); $\mathrm{A}=$ area to

157 be irrigated (acre); and $\mathrm{D}=$ depth of applied irrigation (inch) ${ }^{1}$.

158 Downscaling techniques

Statistical downscaling is a promising approach to formulate specific, local-scale, or level

160 climatic predictions (Laflamme et al. 2015). Statistical downscaling is a computationally less

161 intensive practice to accomplish diverse results at the local scale over dynamics downscaling. It

162 has a two-step process comprising 1) establishing statistical relationships between local-scale

163 climatic variables and large-scale predictors and 2) the implication of corresponding relationships

164 to produce large-scale output to predict local-scale climatic features for the future (Hoar and

165 Nychka 2008). Statistical downscaling modeling (SDSM) is a hybrid decision support tool to

166 examine the impact of climate change. It includes future scenarios, weather generators, and

167 multiple linear regression (MLR) methods for future climate predictions at local, regional, or cross-

168 border (Kazmi et al. 2016; Gebrechorkos et al. 2019; Pomee et al. 2020). Here, CanESM2 climatic

169 variables are used and acquired from https://climate-scenarios.canada.ca/. CanESM2 has historical

170 data of 26 climatic parameters from 1976 to 2005, respectively. Grid data 27 X and 44 Y of

171 CanESM2 were downloaded from the above link. In addition, observed climate data of the

172 Faisalabad station was acquired from Pakistan Metrological Department (PMD). Moreover, it

173 gives future climatic data under different Representative Concentrations Pathways (RCP)

174 scenarios from 2006 to 2100, respectively. These scenarios are based on future projections of GHG

175 (greenhouse gas) emissions. First scenario, RCP 2.6 is based on very low emission of GHG

176 concentration. Second scenario, RCP 4.5, is considered a steady-state scenario to reduce GHG

177 emissions to keep entire radioactive forces stable before 2100 by implementing numerous

${ }^{1}$ Units of the parameters are interchangeable on the basis of required unit of depth. 
178 technologies and strategies. Third scenario, RCP 8.5 is characterized as constantly rising GHG

179 emission for time series. The data is accessible at a grid resolution of $2.8125^{\circ}$ latitude $\times 2.8125^{\circ}$

180 longitudes, respectively.

181 Predictor's screening: the most relevant atmospheric parameters were chosen with the assistance

182 of the MLR model. Selection was based on p-value, histograms, scatterplots, correlation matrix, 183 and partial correlation. A correlation matrix was preferred between predictands and CanESM2 184 predictors (Kobuliev et al. 2021). A predictor parameter, which was positively correlated, has a 185 significant representation in the scatterplot and minimum p-value. Therefore, it was cautiously 186 chosen for maximum and minimum temperature, rainfall, relative humidity, and wind speed. 187 NCEP (National Centers for Environmental Prediction) predictands were different for each 188 parameter and selected based on p-value and partial r-value, respectively.

189 Calibration and validation of SDSM: the model was calibrated for data from 1976 to 1995 and 190 validated from 1996 to 2005 . The model was developed for the daily downscaling of rainfall. A 191 monthly regression equation was applied in eight stations, and a sub-model was used conditionally. 192 Ordinary Least Square (OLS) was used to optimize the model. Data for the calibration period 193 (1976-1995) is used as a base and simulates the daily maximum and minimum temperature, 194 rainfall, relative humidity, and wind speed for the validation period (1996-2005) with the induction 195 of NCEP and CanESM2 predictors, respectively. For better agreement with the results, 100 196 ensembles were used to obtain the average. In literature, some other studies also evaluated the 197 good performance of SDSM compared to other methods; that's why this statistical downscaling 198 approach was used (Kazmi et al. 2016; Khan et al. 2018; Kobuliev et al. 2021). Performance of 199 the model was evaluated by the root mean square error (RMSE), coefficients of correlation $\left(\mathrm{R}^{2}\right)$, 200 and Nash-Sutcliffe Efficiency (NSE) and calculated by Eqs. 1, 2 \&3 as follows: 


$$
R M S E=\sqrt{\frac{1}{2} \sum_{k=1}^{n}\left(X_{k}-Y_{k}\right)^{2}}
$$

$$
R^{2}=\frac{\sum_{k=1}^{n}\left(X_{k}-\bar{X}\right)^{2} \cdot\left(Y_{k}-\bar{Y}\right)^{2}}{\sqrt{\sum_{k=1}^{n}(X-\bar{X})^{2} \cdot \sum_{i=1}^{n}\left(Y_{k}-\bar{Y}\right)^{2}}}
$$

$$
E_{f}=1-\frac{\sum_{k=1}^{n}\left(Y_{k}-X_{k}\right)^{2}}{\sum_{k=1}^{n}\left(X_{k}-\bar{X}\right)^{2}}
$$

204 where $X$ is the observed value, $Y$ is simulated value removal, the $\operatorname{bar}(-)$ represents the mean value, 205 and $n$ is the number of samples.

206 Scenario Generator: is used to simulate the results of future climate scenarios, i.e., RCP2.6, 207 RCP4.5, and RCP8.5, respectively. First, the future climate data of maximum temperature, 208 minimum temperature, rainfall, relative humidity, and wind speed were predicted for 2006 to 2100 209 on a daily basis. Afterward, this data was used to estimate the groundwater recharge flux under 210 different sowing conditions for the cotton field for the two periods, i.e., 2021 to 2050 and 2051 to 2112080.

\section{HYDRUS-1D: Estimation of Recharge Flux}

To simulate groundwater recharge flux, unsaturated flow models were developed for each

214 treatment, i.e., $\mathrm{T}_{1}, \mathrm{~T}_{2}, \mathrm{~T}_{3}, \mathrm{~T}_{4}, \mathrm{~T}_{5}$, and $\mathrm{T}_{6}$, respectively. Richard's convection-dispersion equations

215 were espoused to account for the water flow under the cotton field. HYDRUS-1D code was run to 216 simulate the one-dimensional flow based on Eq. 4 (Šimůnek et al. 2013). HYDRUS-1D was 217 acquired from the public domain PC-PROGRESS - Hydrus-1D (pc-progress.com).

$$
\frac{\partial \theta}{\partial t}=\frac{\partial}{\partial z}\left[K(h) \frac{\partial h}{\partial z}+K(h)\right]-S(h)
$$

219 where $\theta$ is the volumetric soil water content $\left(\mathrm{cm}^{3} \mathrm{~cm}^{-3}\right)$; $\mathrm{t}$ is time (day); $\mathrm{h}$ is the soil-water pressure 220 head (cm); $\mathrm{z}$ is the gravitational head as well as the vertical coordinate ( $\mathrm{cm}$, upwards is positive); 
$221 \mathrm{~K}(\mathrm{~h})$ is the unsaturated hydraulic conductivity $\left(\mathrm{cm} \mathrm{d}^{-1}\right)$, and $\mathrm{S}$ is the soil water extraction rate by 222 plant roots $\left(\mathrm{cm}^{3} \mathrm{~cm}^{-3} \mathrm{~d}^{-1}\right)$.

The soil hydraulic properties of soil were elucidated by the Mualem-van Genuchten

224 formulation (Mualem 1976; van Genuchten 1980), based on the pore-size distribution in the model

225 by Eq 5 \& 6, respectively;

$226 S_{e}=\frac{\theta-\theta_{r}}{\theta_{s}-\theta_{r}}=\left(1+\alpha_{r}|h|^{n}\right)^{-m}$

$227 K(h)=K_{S} S_{e}{ }^{l}\left[1-\left(1-S_{e}{ }^{1 / m}\right)^{m}\right]^{2}$

228 where $S_{\mathrm{e}}$ is effective saturation $[-] ; \theta_{\mathrm{r}}$ and $\theta_{\mathrm{s}}$ are residual and saturated water contents $\left[\mathrm{cm}^{3} \mathrm{~cm}^{-3}\right]$, 229 respectively; and $\alpha \mathrm{r}[\mathrm{cm}-1], \mathrm{m}[-]$ and $\mathrm{n}[-]$ are shape parameters. $\mathrm{K}_{\mathrm{s}}$ is the saturated hydraulic 230 conductivity $[\mathrm{cm} \mathrm{d-1];} 1[-]$ is a pore connectivity parameter; and $\mathrm{m}=1-1 / \mathrm{n}$, when $\mathrm{n}>1$. The 231 percentage of sand, silt, and clay and Bulk density and van Genuchten parameters were given in 232 Table-1.

233 Table-1: Soil properties of experimental site including particle-size distribution at different 234 depths by weight percentage of particle-diameter intervals (sand, silt, and clay), and van 235 Genuchten parameters

\begin{tabular}{ccccccc}
\hline Depth (cm) & Sand (\%) & Silt (\%) & Clay (\%) & Bulk Density $\left(\mathrm{g} \mathrm{cm}^{-3}\right)$ & $\theta_{\mathrm{i}}\left(\mathrm{cm}^{3} \mathrm{~cm}^{-3}\right)$ & $\theta_{\mathrm{r}}\left(\mathrm{cm}^{3} \mathrm{~cm}^{-3}\right)$ \\
\hline $0-30$ & 74.25 & 12.35 & 13.40 & 1.660 & 0.0809 & 0.04 \\
$30-60$ & 73.33 & 12.62 & 14.05 & 1.650 & 0.1401 & 0.05 \\
$60-90$ & 73.5 & 12.80 & 13.75 & 1.642 & 0.1408 & 0.05 \\
\hline
\end{tabular}

236

237

238

239

240

241

At first, the model's domain and soil parameters were conventional taken into account by the measured particle-size distributions (Table 1) and monitored moisture contents at different depths (0-30, 30-60, and 60-90 cm), respectively. Subsequently, undergoing model calibration, soil parameters were slightly modified to best fit corresponding observations and model predictions. 
Flow model: Boundary and Initial Conditions

The top boundary condition was selected as a cotton crop field that ultimately depended upon evapotranspiration, irrigation, and rainfall. For this study, reference evapotranspiration $\left(\mathrm{ET}_{0}\right)$ was estimated with the Penman-Monteith equation using the NIAB meteorological station's recorded data. The bottom boundary condition was selected as a free drainage boundary condition to estimate the root zone's recharge flux. To calculate the root water uptake (transpiration), the proposed method to include osmotic stress was applied as represented in Eq. 7 (van Genuchten 1987). In the current study, the multiplicative threshold model was used.

$$
\alpha\left(h, h_{\phi}\right)=\frac{1}{1+\left(h / h_{50}\right)^{P_{1}}} \frac{1}{1+\left(h_{\phi} / h_{\phi 50}\right)^{P_{2}}}
$$

251 where $\mathrm{p}_{1}, \mathrm{p}_{2}$ are experimental constants; $\mathrm{h}_{50}$ is the pressure head at which the water extraction rate 252 is reduced by $50 \%$ during conditions of negligible osmotic stress, and $h \varphi_{50}$ is the osmotic head at 253 which the water extraction rate is reduced by $50 \%$ during negligible water stress. The Feddes 254 parameter values for root water uptake for the cotton crop were estimated by is given in Table 2.

\section{Table 2: Root Water Uptake Parameters for Cotton Crop.}

P.O. (cm): Value of the pressure head below which roots start to extract water from the soil.

POpt (cm): Value of the pressure head below which roots extract water at the maximum possible rate

$\mathrm{P} 2 \mathrm{H}(\mathrm{cm})$ : Value of the limiting pressure head below which roots can no longer extract water at the maximum rate (assuming a potential transpiration rate of $r 2 \mathrm{H}$ ).

P2L (cm): As above, but for a potential transpiration rate of $r 2 L$.

P3 (cm): Value of the pressure head below which root water uptake ceases (usually taken at the wilting point).

$\mathrm{r} 2 \mathrm{H}\left(\mathrm{cm} /\right.$ days): Potential transpiration rate $\left[\mathrm{LT}^{-1}\right]$ (currently set at $0.5 \mathrm{~cm} /$ day).

$\mathrm{r} 2 \mathrm{~L}$ (cm/days): Potential transpiration rate $\left[\mathrm{LT}^{-1}\right]$ (currently set at $0.1 \mathrm{~cm} /$ day).

The water balance of the vertical soil domain covered by vegetation for a given period is the governing equation. There was no runoff during irrigation. The cotton plants' interception of rainwater was also neglected due to low rainfall amounts during the vegetation period. Potential 
260 evapotranspiration ( $\mathrm{ET}_{\mathrm{o}}$ ) was calculated by FAO-56 standards using the Penman-Monteith

261 method. Meanwhile, crop evapotranspiration $\left(\mathrm{ET}_{\mathrm{c}}\right)$ was computed by defining the regional crop

262 coefficient $\left(\mathrm{K}_{\mathrm{c}}\right)$ based on initial-season, mid-season, late-season, and evaporation soil,

263 respectively. Evaporation from the soil is predicted by the estimation of energy available at the

264 soil surface.

265 Model Calibration and prediction

266 Model calibration is typically defined as turning a model by interpreting the input

267 parameters, i.e., soil hydraulic parameters and boundary and initials conditions. The foremost

268 objective of the flow model's calibration is to fit the simulated model results and the observed

269 value of soil moisture or water content under the cotton field. Inverse estimation methods were

270 used to achieve the objective by determining unsaturated soils' hydraulic properties (Bitterlich et

271 al. 2004). The water flows and salt transport are case sensitive to soil hydraulic functions $[\theta(\mathrm{h})$ and

$272 \mathrm{~K}(\theta)$ ]. Meanwhile, pedotransfer functions were applied to predict water retention parameters and

273 saturated hydraulic conductivity from soil texture and bulk density (Van Looy et al. 2017). These

274 estimations were refined by induction of input data of one or two water retention points.

275 Consequently, the hydraulic properties were calibrated to site-specific conditions. For this purpose,

276 soil moisture, tension, and salinity data were measured every fifth day before and after irrigation.

The HYDRUS-1D model was calibrated against the moisture content during the cotton

278 crop period. Results were evaluated against two statistical parameters: $\mathrm{R}^{2}$ and RMSE, calculated

279 by Eq. 1 \& 2 for calibration and validation. The calibration parameter is the soil moisture content

280 that was taken at a regular interval of time. 


\section{Statistical analysis}

A correlation and multivariate regression model were conditioned to affirm the impact of climate change on groundwater recharge. Microsoft Excel® 2019 ads-in data analysis tool was used to develop a correlation and multivariate regression model. The linear relationship between tended groundwater recharge and climate variables was established to determine the groundwater recharge flux. These relationships were resultant as follows:

$$
\Delta X=\text { constant }+\beta_{1} \Delta T_{\max }+\beta_{2} \Delta T_{\max }+\beta_{3} \Delta R_{f}+\beta_{4} \Delta R_{H}+\beta_{5} \Delta W_{s}
$$

where, $\Delta X$ is the groundwater recharge flux in cotton crop, $\beta_{1}, \beta_{2}, \beta_{3}, \beta_{4}$, and $\beta_{5}$ are the coefficient of maximum temperature $\left(\mathrm{T}_{\max }\right)$, minimum temperature $\left(\mathrm{T}_{\min }\right)$, rainfall $\left(\mathrm{R}_{\mathrm{f}}\right)$, relative humidity $\left(\mathrm{R}_{\mathrm{H}}\right)$, and wind speed $\left(\mathrm{W}_{\mathrm{S}}\right)$, respectively. While $\Delta$ representing the change in climate variables.

\section{RESULTS AND DISCUSSIONS}

\section{Future Climate Trends}

The downscaling was performed using SDSM for the Faisalabad station. The 30 years (1975-2005) data were used for calibration (1975-1995) and validation (1996- 2005). Robustness of downscaling was evaluated by $\mathrm{R}^{2}$, RMSE, and NSE for both calibration and validation phases (Table 3). The results show that accuracy downscaling in the reproduction of climate parameters is based on high $\mathrm{R}^{2}(>0.96)$ and low $\mathrm{RMSE}(<0.4)$ for both calibration and validation period, consequently. Besides, Nash-Sutcliffe Efficiency (>0.95 1.0) is elucidated the good efficiency or better fitting of data. This performance analysis has shown better agreement than the previous study (Bessah et al. 2021). The CanSME2 GCM data was used for future climate generation under three emission scenarios, i.e., RCP 2.6, RCP 4.5, and RCP 8.5. The different NCEP predictors 
were used for each parameter with the correlation method and the confidence level of $95 \%$ for 304 every climatic parameter. Long-term discrepancies in climate change parameters were 305 investigated, i.e., maximum and minimum temperature, rainfall, relative humidity, and wind speed, 306 respectively, for future 2021-2050 and 2051-80 under three emission scenarios, i.e., RCP 2.6, RCP $307 \quad 4.5$, and RCP 8.5.

Table 3: Evaluation of climatic parameters for calibration (1975-1995) and validation $309 \quad(1996-2005)$ phase

\begin{tabular}{llll|lll}
\hline Climate parameters & \multicolumn{4}{l}{ Calibration } & \multicolumn{2}{l}{ Validation } \\
\cline { 2 - 7 } & \multicolumn{2}{l}{$\mathbf{R}^{\mathbf{2}}$ RMSE } & NSE & $\mathbf{R}^{2}$ & RMSE & NSE \\
\cline { 2 - 7 } Maximum temperature & 0.965 & 0.348 & 0.973 & 0.975 & 0.221 & 0.981 \\
Minimum temperature & 0.997 & 0.033 & 0.996 & 0.961 & 0.365 & 0.979 \\
Rainfall & 0.976 & 0.343 & 0.884 & 0.959 & 0.376 & 0.879 \\
Relative humidity & 0.980 & 0.113 & 0.959 & 0.986 & 0.110 & 0.968 \\
Wind speed & 0.988 & 0.077 & 0.986 & 0.973 & 0.367 & 0.969 \\
\hline
\end{tabular}

$3122.11(0.91)^{\circ} \mathrm{C}$, and $2.18(1.07){ }^{\circ} \mathrm{C}$ under RCP 2.6, RCP 4.5, and RCP 8.5, respectively, for 2021-50

313 (Table 4). During 2051-80, this annual increment in maximum (minimum) temperatures was 314 higher significantly $3.40(1.06){ }^{\circ} \mathrm{C}, 3.64(1.51){ }^{\circ} \mathrm{C}$, and $4.04(2.18)^{\circ} \mathrm{C}$ under RCP $2.6, \mathrm{RCP} 4.5$, and 315 RCP 8.5, respectively. This increasing trend of temperature is similar to previous reports lately 316 (Arshad et al. 2019; Saddique et al. 2020). Meanwhile, the maximum (minimum) temperature 317 range is projected to increase between $5.7(0.8){ }^{\circ} \mathrm{C}$ annually by the late 21 st century (Dahri et al. 318 2021). However, the expected rise of maximum (minimum) temperature by 2.03 to 4.04 (0.8 to $3192.18)^{\circ} \mathrm{C}$, that's the proximity of global emission consequence by 3 to $5^{\circ} \mathrm{C}$ rise in temperature in 320 Pakistan (Chaudhry 2017). Rainfall decline gradually, 48.22 to $41.68 \mathrm{~mm}, 47.92$ to $41.41 \mathrm{~mm}$, and 
322 of the study would also be shifted from June-July to early April-May. Relative humidity and wind

323 speed declined significantly from 10.20 to $10.53 \%$ and 0.95 to $0.69 \mathrm{~km} . \mathrm{hr}^{-1}$ for the 2051-80

324 periods (Table 4). These climate variables are influential in evaluating the blue water footprint

325 under cotton fileds (Huang et al. 2019) and may cause a diminution of groundwater recharge.

326 Table 4: Predicted relative changes in average values future climatic parameters under RCP 2.6,

RCP 4.5, and RCP 8.5

\begin{tabular}{lccc|ccc}
\hline \multicolumn{1}{c}{ Parameters } & \multicolumn{3}{c|}{ 2021-2050 } & \multicolumn{3}{c}{ 2051-2080 } \\
\cline { 2 - 7 } & RCP 2.6 & RCP 4.5 & RCP 8.5 & RCP 2.6 & RCP 4.5 & RCP 8.5 \\
\hline Max. temperature (C) & 2.03 & 2.11 & 2.18 & 3.40 & 3.64 & 4.04 \\
Min temperature (C) & 0.80 & 0.91 & 1.07 & 1.06 & 1.51 & 2.18 \\
Rainfall (mm) & 48.22 & 47.92 & 47.75 & 41.68 & 41.41 & 40.18 \\
Relative humidity (\%) & -4.52 & -4.42 & -4.37 & -10.20 & -10.33 & -10.35 \\
Wind speed (km/hr) & -0.40 & -0.37 & -0.35 & -0.95 & -0.85 & -0.69 \\
\hline
\end{tabular}

The HYDRUS-1D model's calibration was undertaken by comparing the observed and simulated moisture content at $30 \mathrm{~cm}, 60 \mathrm{~cm}$, and $90 \mathrm{~cm}$ depth, respectively. Observations nodes on experimental data of pressure heads were shown maximum hydraulic head at $30 \mathrm{~cm}$ and minimum hydraulic head at $90 \mathrm{~cm}$ depth with a seven-day interval of moisture content of the entire 334 cotton season. Observation nodes of simulated moisture content were shown homogenous pattern 335 (Fig. 3) of moisture content at $30 \mathrm{~cm}, 60 \mathrm{~cm}$, and $90 \mathrm{~cm}$ respectively under six treatments $\left(\mathrm{T}_{1}, \mathrm{~T}_{2}\right.$, $\mathrm{T}_{3}, \mathrm{~T}_{4}, \mathrm{~T}_{5}$, and $\mathrm{T}_{6}$ ) into the soil profile. Consequently, maximum water content was simulated at

$33730 \mathrm{~cm}$ depth, and minimum water content was simulated at $90 \mathrm{~cm}$ depth regardless of the mulching and sowing method. The cotton field's water content exhibited erratic fluctuations in water content 
during the season due to surface water inducing irrigation and rainfall. Herein, HYDRUS-1D made an efficient operation by predicting the time which water content arises. Nevertheless, the observed data showed a faster decrease in water content than predicted by HYDRUS-1D. This discrepancy in the top layer $(30 \mathrm{~cm})$ would be ascribed to more rapid drainage (sandy loam soil) or higher evapotranspiration rates by cotton plants. The model was run under a ten-time step (0-10) and generated a hydraulic conductivity profile and soil layers' hydraulic capacity. Hydraulic conductivity increased to a certain depth of soil after it became constant (Fig. 4a). It is a critical parameter to access the water flow into the soil stratum. Hydraulic capacity represented the amount of water conveyed through steady and uniform gravity flow (Fig. 4b).

In general, the simulated moisture content $\left(\mathrm{cm}^{3} . \mathrm{cm}^{-3}\right)$ by HYDRUS-1D at $30 \mathrm{~cm}, 60 \mathrm{~cm}$, and $90 \mathrm{~cm}$ depths corresponded in close proximity to the observed moisture content $\left(\mathrm{cm}^{3} . \mathrm{cm}^{-3}\right)$ for six treatments. Nevertheless, deviations between simulated and observed moisture content exhibited at certain depths (e.g., $60 \mathrm{~cm}$ depth) at treatment $\mathrm{T}_{6}$. Moreover, the observed moisture content was apparently higher than the simulated moisture content at $30 \mathrm{~cm}$ depth for $\mathrm{T}_{4}$ and $\mathrm{T}_{6}$. It could be due to the sowing of cotton without mulching. The robustness of the HYDRUS-1D is evaluated based on $\mathrm{R}^{2}$ and RMSE values, as shown in Table 5. The $\mathrm{R}^{2}$ and RMSE values for the HYDRUS-1D model were ranged between 0.81and 0.92, and 3.40E-3 and 6.55E-5, respectively. Overall, the average $\mathrm{R}^{2}(0.875)$ and RMSE (5.24E-4) were reliable through the whole soil profile. These results show consistency with previously groundwater recharge flux estimation using HYDRUS-1D under agricultural fields (Turkeltaub et al. 2014; Xi et al. 2016; Boughanmi et al. 2018). Thus, calibrated HYDRUS-1D model has indicated excellent performance, afterward used to simulating the one-dimensional soil water dynamics in cotton irrigated fields for all six treatments. 


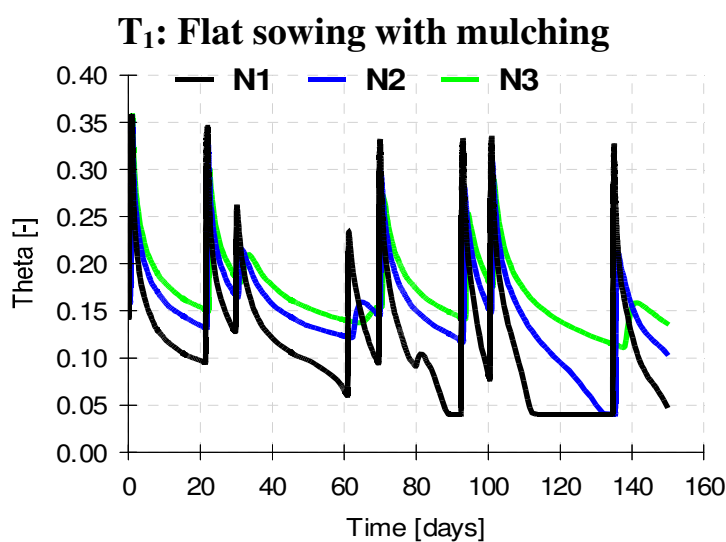

$T_{3}$ : Ridge sowing with mulching

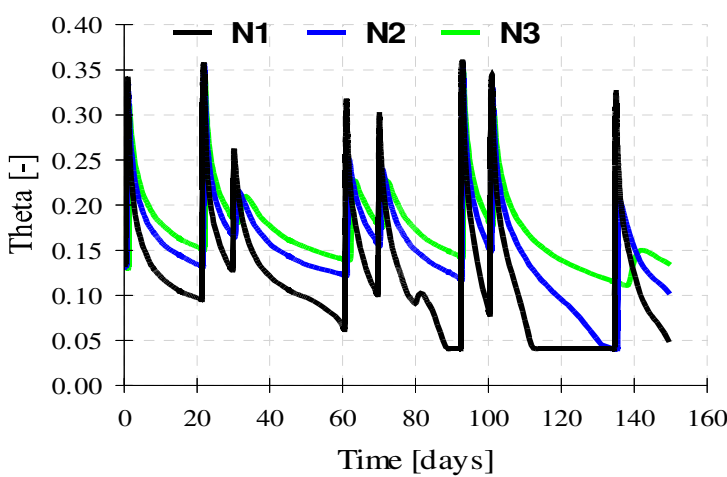

$\mathrm{T}_{5}$ : Bed planting with mulching

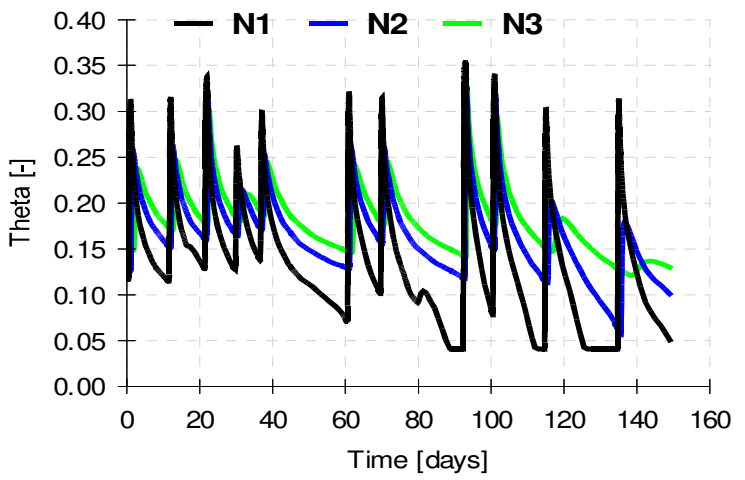

$\mathrm{T}_{2}$ : Flat sowing without mulching

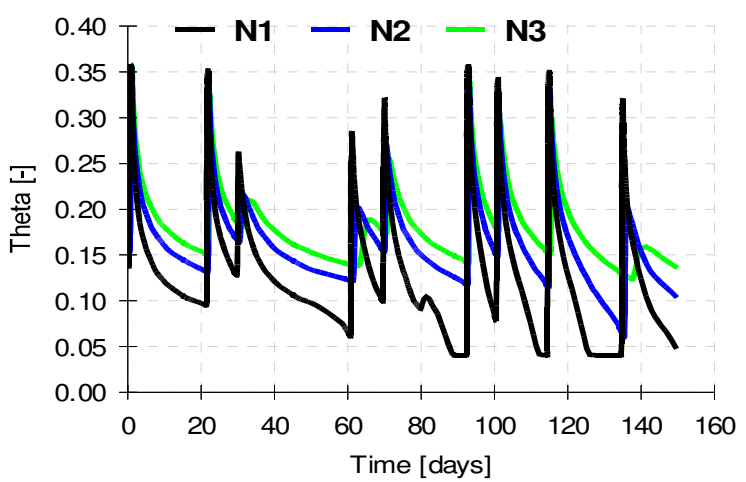

T4: Ridge sowing without mulching

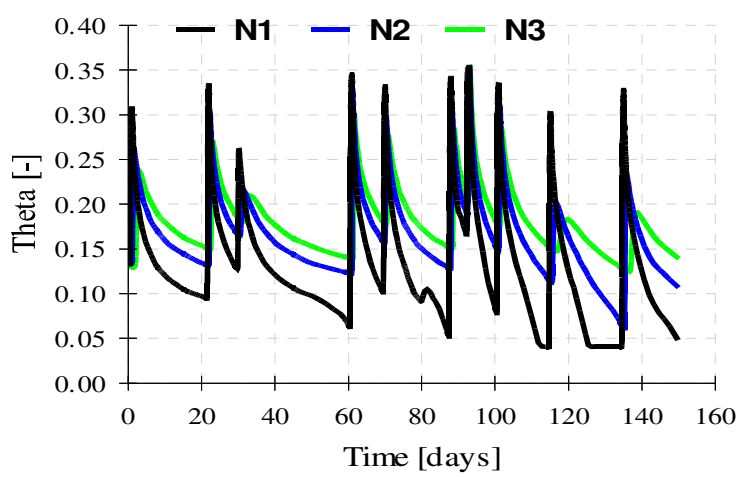

$\mathrm{T}_{6}$ : Bed planting without mulching

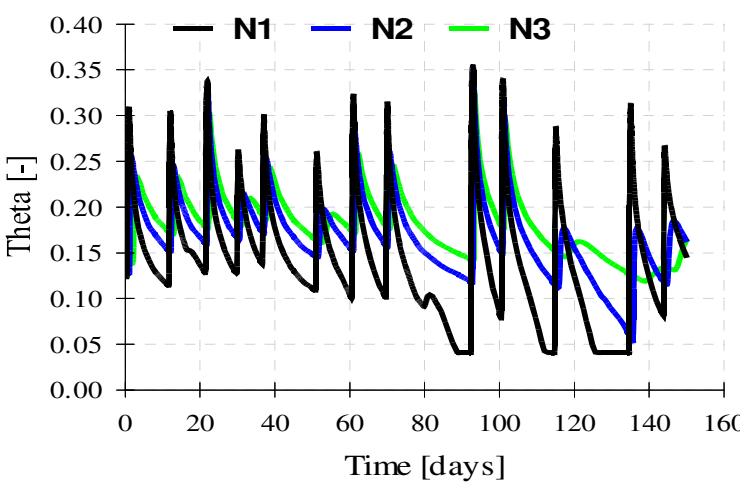

362 Figure 3: observations nodes of simulated water content at $\mathrm{N}_{1}(30 \mathrm{~cm}), \mathrm{N}_{2}(60 \mathrm{~cm})$, and $\mathrm{N}_{3}(90$ $\mathrm{cm})$ under six treatments $\left(\mathrm{T}_{1}, \mathrm{~T}_{2}, \mathrm{~T}_{3}, \mathrm{~T}_{4}, \mathrm{~T}_{5}\right.$, and $\left.\mathrm{T}_{6}\right)$. 
(a)

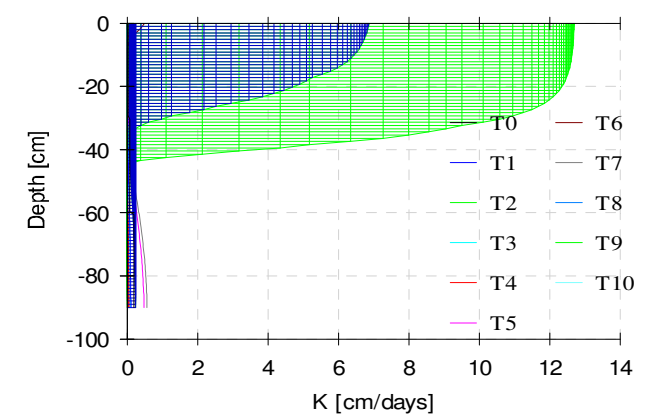

(b)

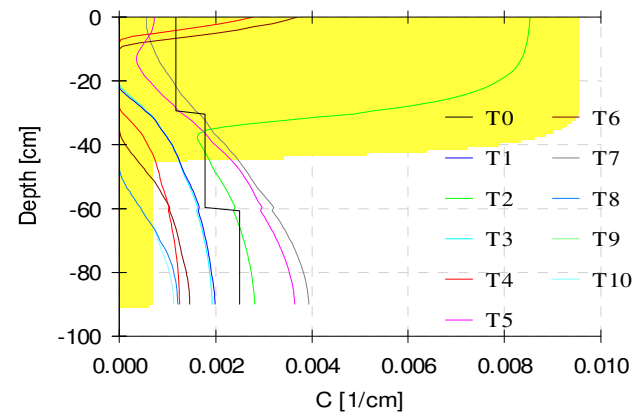

364 Figure 4: profile information of soil (a) hydraulic conductivity and (b) hydraulic capacity under ten-time step

366 Table-5: $\mathrm{R}^{2}$ and RMSE values between observed and simulated moisture content at different 367 depths and treatments.

\begin{tabular}{cccc|ccc}
\hline \multirow{2}{*}{$\begin{array}{c}\text { Treatment } \\
\text { Depth }\end{array}$} & \multicolumn{3}{c|}{$\mathrm{R}^{2}$} & \multicolumn{3}{c}{ RMSE } \\
\cline { 2 - 7 } & $30 \mathrm{~cm}$ & $60 \mathrm{~cm}$ & $90 \mathrm{~cm}$ & $30 \mathrm{~cm}$ & $60 \mathrm{~cm}$ & $90 \mathrm{~cm}$ \\
\hline $\mathrm{T}_{1}$ & 0.89 & 0.86 & 0.85 & $1.00 \mathrm{E}-3$ & $1.50 \mathrm{E}-3$ & $1.50 \mathrm{E}-4$ \\
$\mathrm{~T}_{2}$ & 0.92 & 0.91 & 0.87 & $1.20 \mathrm{E}-4$ & $2.50 \mathrm{E}-4$ & $4.20 \mathrm{E}-5$ \\
$\mathrm{~T}_{3}$ & 0.85 & 0.89 & 0.82 & $6.55 \mathrm{E}-5$ & $1.50 \mathrm{E}-4$ & $3.25 \mathrm{E}-5$ \\
$\mathrm{~T}_{4}$ & 0.92 & 0.86 & 0.91 & $6.55 \mathrm{E}-5$ & $1.80 \mathrm{E}-4$ & $3.22 \mathrm{E}-5$ \\
$\mathrm{~T}_{5}$ & 0.91 & 0.86 & 0.87 & $2.77 \mathrm{E}-5$ & $6.55 \mathrm{E}-5$ & $1.40 \mathrm{E}-3$ \\
$\mathrm{~T}_{6}$ & 0.89 & 0.82 & 0.85 & $3.40 \mathrm{E}-3$ & $5.40 \mathrm{E}-4$ & $4.10 \mathrm{E}-4$ \\
\hline
\end{tabular}




\section{Groundwater recharge}

The calibrated HYDRUS-1D model for the irrigated cotton field was run over 150 days at a daily resolution to estimate all fluxes, including actual root water uptake, bottom flux, surface runoff, infiltration rate, cumulative evaporation, and soil water storage into the root zone. Boundary fluxes under the flat sowing of the cotton crop with mulch cover in Fig. 5 during the season. Actual root water uptake $\left(\mathrm{cm} \cdot \mathrm{day}^{-1}\right)$ was minimum during 20-40 days and maximum at the $130^{\text {th }}$ day after cotton sowing (Fig. 5a). The cotton crop's cumulative root water uptake is about 62 $\mathrm{cm}$ during the $150^{\text {th }}$ day after sowing (Fig. 5b). Bottom flux $\left(\mathrm{cm}^{- \text {day }^{-1}}\right)$ below the root zone was

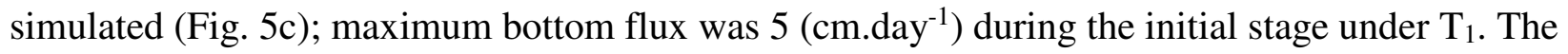
cumulative/ total recharge flux was $55 \mathrm{~cm}$ approximately during the cotton season under $\mathrm{T}_{1}$ (Fig. 5d). The amount of water that infiltrates below the root zone directly or indirectly turns into groundwater recharge.

Recharge during irrigated crop season has a fractional amount under a seven-day rotational program (warabandi system) based on the supply instead of the demand. Daily soil water storage under $\mathrm{T}_{1}$ has a maximum value of $25 \mathrm{~cm}$ on the $20^{\text {th }}$ day and a minimum value of $5 \mathrm{~cm}$ on the $138^{\text {th }}$ day after cotton sowing (Fig. 5e). The soil moisture content store at this layer could maximize the cotton yield and water productivity (Wang et al. 2020). This stored water content is used by the cotton crop when a deficit of irrigation. The total depth of water infiltrated from the ground surface to the subsurface (Fig. 5f), approximately $110 \mathrm{~cm}$ during crop duration under $\mathrm{T}_{1}$. In this circumstance, the surface runoff is negligible due to small land units or small experimental plots and low rainfall during the simulation period. However, the surface runoff may be increased under changing climate scenarios. Cumulative evaporation from the ground surface is minimum (Fig. $5 \mathrm{~g}$ ); approximately $0.6 \mathrm{~cm}$ of water was evaporated from the soil surface into the atmosphere. All 
392 boundary fluxes are shown in Fig. 5h, including potential and actual surface flux, potential and 393 actual root water uptake, and actual bottom flux. It reflects that the potential root water uptake is 394 higher than the actual root water uptake. All fluxes were estimated in the vadose zone of soil using 395 the water budget approach in HYDRUS-1D (Fig. 6).

Similarly, all fluxes were estimated for the remaining five treatments $T_{2}, T_{3}, T_{4}, T_{5}$, and $T_{6}$ using HYDRUS-1D. Cumulative recharge, cumulative actual water uptake, cumulative infiltration 398 for all the six treatments have been calculated and compared (Fig. 7). Noteworthy, the maximum 399 cumulative recharge was occurred under $\mathrm{T}_{2}(75 \mathrm{~cm})$, followed by $\mathrm{T}_{4}(70 \mathrm{~cm})$ and $\mathrm{T}_{5}(62 \mathrm{~cm})$. 400 Moreover, the crop's cumulative actual root water uptake was highest under $\mathrm{T}_{6}(83 \mathrm{~cm})$, followed 401 by $\mathrm{T}_{5}(78 \mathrm{~cm})$ and $\mathrm{T}_{4}(72 \mathrm{~cm})$. The estimated cumulative infiltration was observed maximum under $402 \mathrm{~T}_{2}(140 \mathrm{~cm})$ and $\mathrm{T}_{4}(140 \mathrm{~cm})$. Mulching of cotton crops under $\mathrm{T}_{1}, \mathrm{~T}_{3}$, and $\mathrm{T}_{5}$ has reduced soil water 403 content drainage due to climate variability, i.e., rainfall. Mulching has a decisive influence on a 404 water-saving strategy to mitigate water stress in agriculture in rain-fed or semi-arid crop cultivation 405 areas. Meanwhile, the cumulative water fluxes were reported more in flood irrigation over mulched 406 drip irrigation (Jin et al. 2018). Besides, the bed planting (conventional row spacing) of cotton has 407 shown ameliorative plant growth, nutrients uptake, and efficient use of available water resources 408 (Hussain et al. 2021). Therefore, the estimated results strengthen all other advantages of bed 409 planting, i.e., water-saving, uniform distribution, good crop. It also highlighted the disadvantages 410 of flat sowing's higher water loss. 
(a) Actual root water uptake

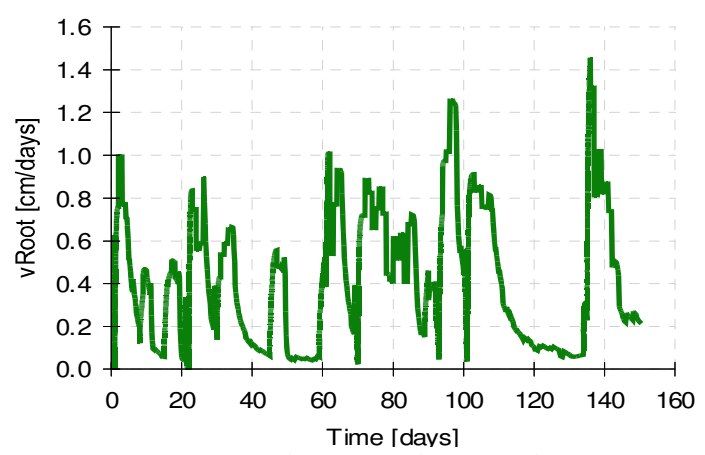

(c) Bottom Flux (Recharge Flux)

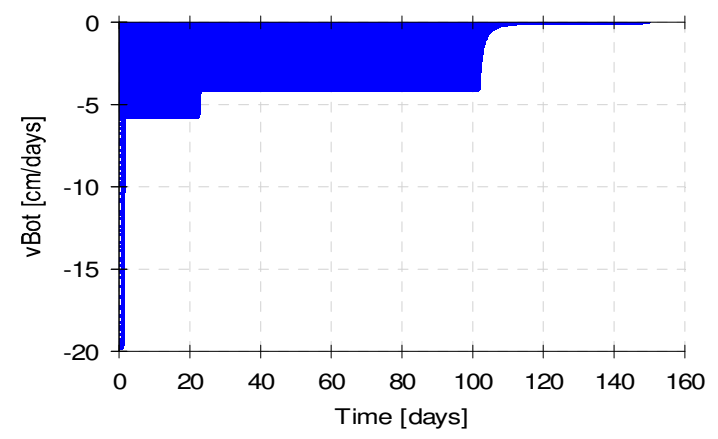

(e) Soil water storage

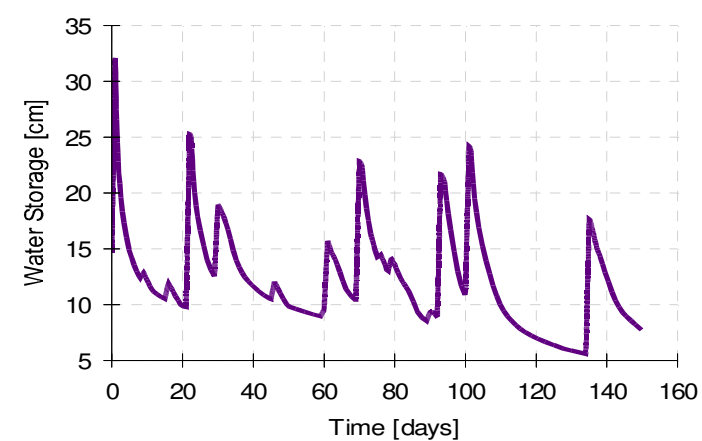

(g) Cumulative Evaporation

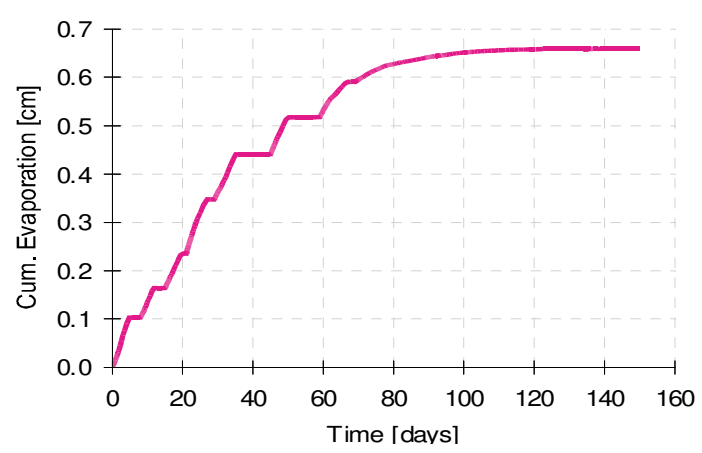

(b) Cumulative Actual root water uptake

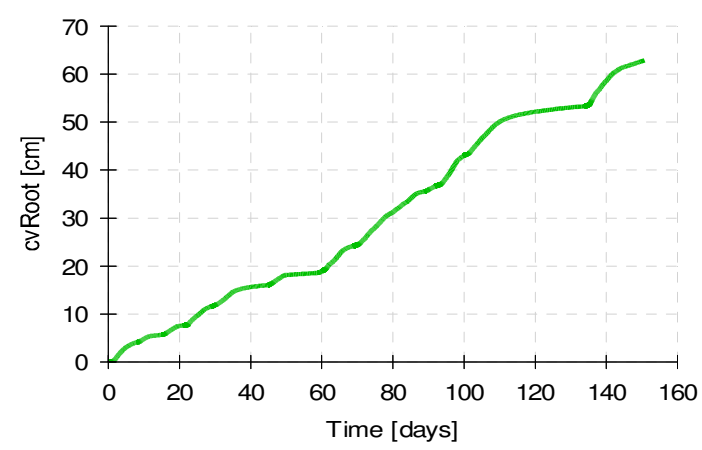

(d) Cumulative Recharge Flux

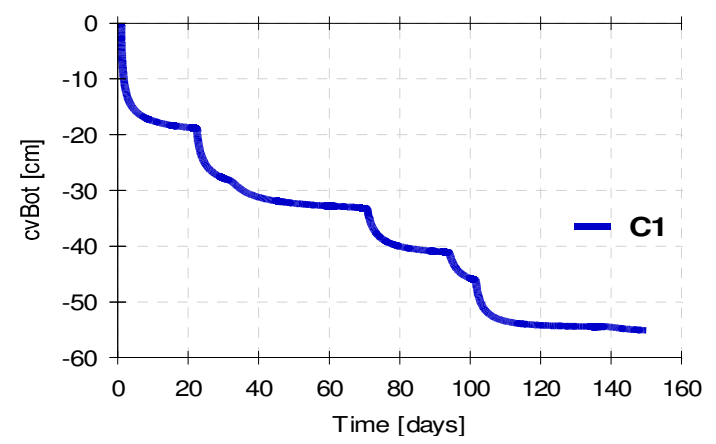

(f) Cumulative Infiltration

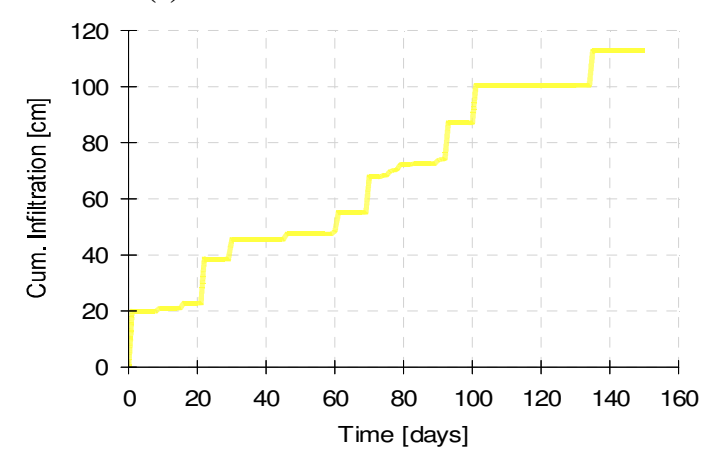

(h) All Cumulative Fluxes

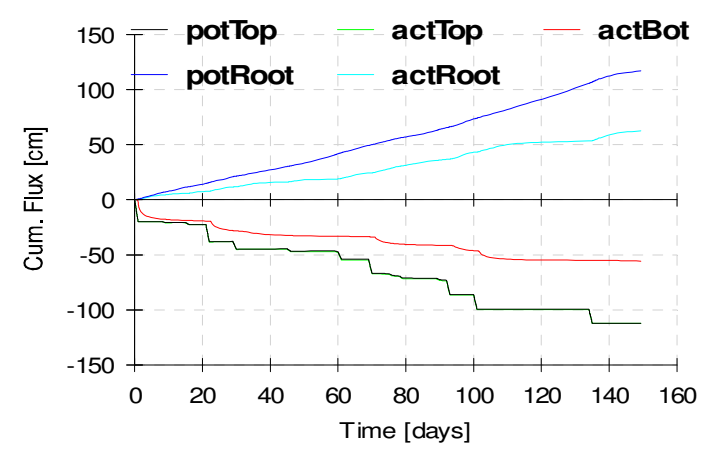

Figure 5(a-h): Boundary fluxes under flat sowing with mulch 


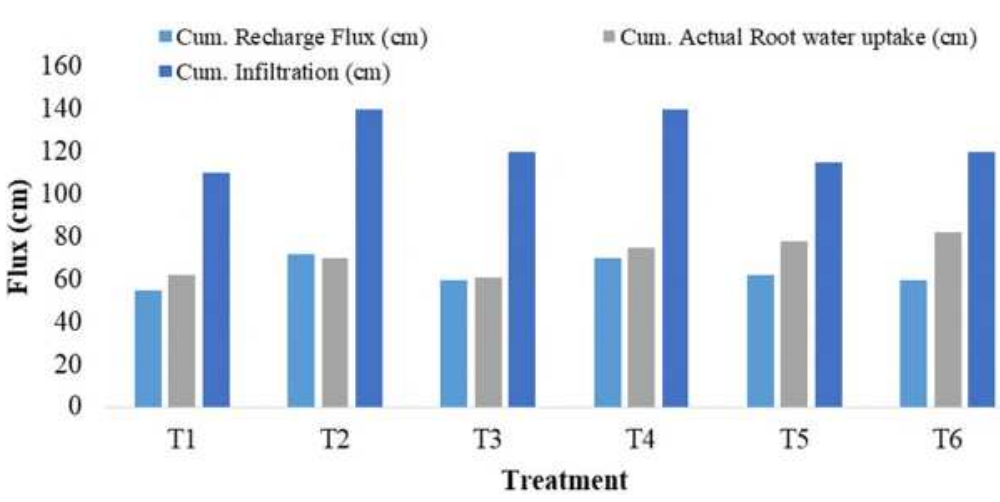

420

Figure 6: Fluxes simulated using HYDRUS-1D for six treatments

$\mathbf{T}_{2}$

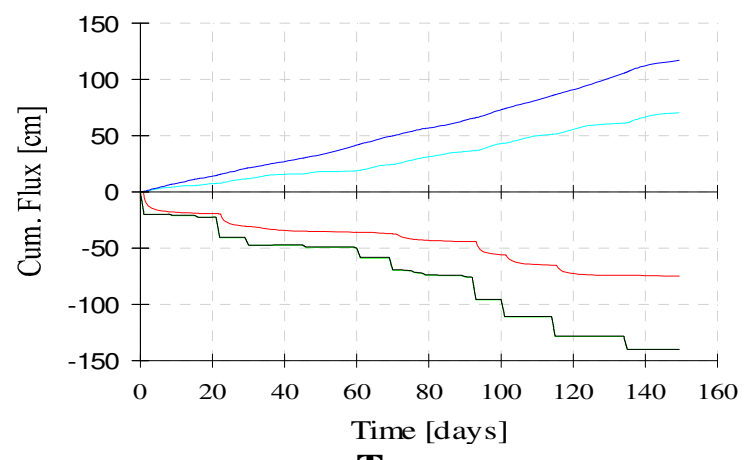

$\mathbf{T}_{4}$

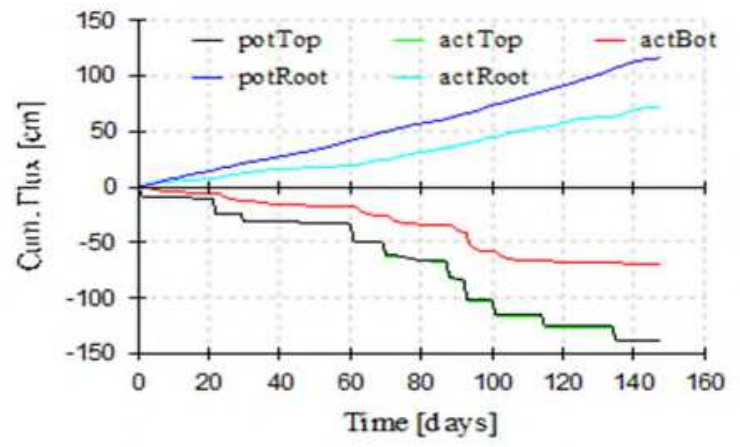

$\mathbf{T}_{3}$

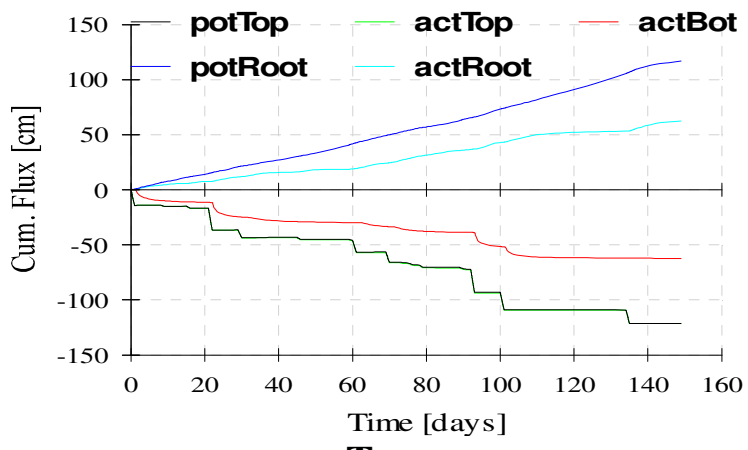

$\mathbf{T}_{5}$

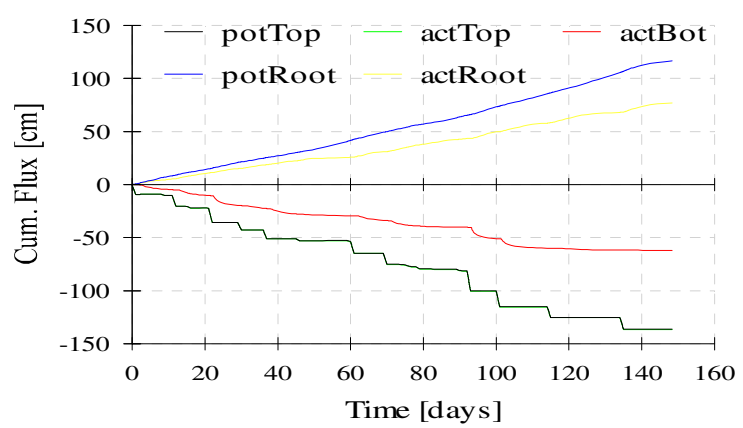

$\mathbf{T}_{6}$

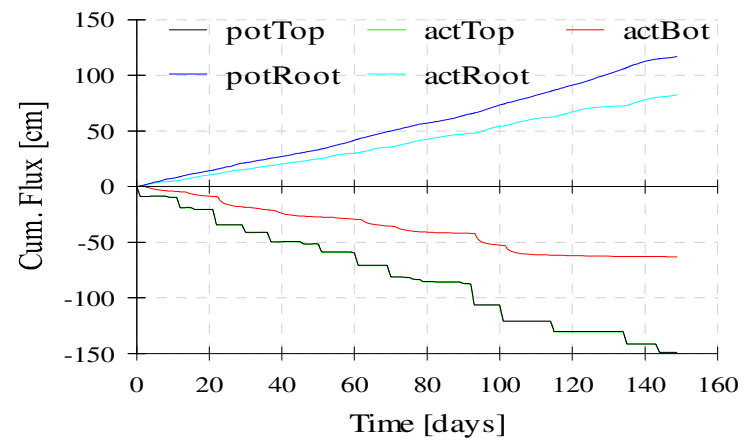

422 Figure 7: all cumulative simulated fluxes of irrigated cotton field using HYDRUS-1D under $\mathrm{T}_{2}, \mathrm{~T}_{3}, \mathrm{~T}_{4}, \mathrm{~T}_{5}$, and $\mathrm{T}_{4}$ 


\section{Impact of Climate Change on Groundwater Recharge}

Herein, climate change on groundwater recharge with mulching was not calculated because of two factors: continuously reporting the plastic mulching's detrimental effect in the agrosystem (Qi et al. 2020; Amare and Desta 2021). That may lead to a ban in the future-another one, the insight that groundwater recharge won't be attained via plastic mulching. Therefore, the impact of climate change on groundwater recharge was calculated without mulching under treatment $T_{2}, T_{4}$, and $\mathrm{T}_{6}$ for 2021-50 and 2061-80 under RCP 2.6, RCP 4.5, and RCP 8.5 in terms of recharge rate, root water uptake, infiltration rate, and evaporation (Fig. 8). The cumulative actual root water uptake $(\mathrm{cm})$ increased for treatment $\mathrm{T}_{2}$ and $\mathrm{T}_{4}$ gradually for 2021-50 and 2051-80 (Fig. 8a \& e). Cumulative recharge flux $(\mathrm{cm})$ decreased under $\mathrm{T}_{2}, \mathrm{~T}_{4}$, and $\mathrm{T}_{6}$ (Fig. $\left.8 \mathrm{~b}, \mathrm{f}, \& \mathrm{j}\right)$. Reduction of groundwater recharge flux could be a potential threat to the socio-ecological balance of the region (Rodríguez-Huerta et al. 2020), up to a 6.6\% decrease in groundwater recharge reported under flood irrigation in the Mediterranean region (Pool et al. 2021). The highest recharge was observed $71 \mathrm{~cm}$ for 2051-80 under $\mathrm{T}_{2}$ for RCP 2.6 (Fig. 8b), while the lowest recharge was $30 \mathrm{~cm}$ for 202150 under $\mathrm{T}_{6}$ for RCP 8.5 (Fig. 8j). Overall, a maximum of $41 \mathrm{~cm}$ of recharge reduction was observed. There wasn't any significant change in cumulative infiltration for 2021-50 and 2051-80 (Fig. 8c, g \& k). Cumulative evaporation increased significantly for 2021-50 and 2051-80 under treatment $\mathrm{T}_{2}, \mathrm{~T}_{4}$, and $\mathrm{T}_{6}$ (Fig. 8d, h \& 1). Overall, the magnitude of actual root water uptake, recharge flux, infiltration, and evaporation of 2051-2080 was more than 2021-50 for RCP 2.6, RCP 4.5, and RCP 8.5 under treatment $\mathrm{T}_{2}, \mathrm{~T}_{4}$, and $\mathrm{T}_{6}$. The increment in actual root water uptake and evaporation may attribute to an increase in temperature for 2021-50 and 2051-80. Meantime, the top layer of soil $(0-20 \mathrm{~cm})$ has a higher temperature $\left(3-6^{\circ} \mathrm{C}\right)$ with an exponential functional relationship between temperature and root water uptake, increasing water uptake (Lv et al. 2013; 
Resende et al. 2019). As water is allocated in the region, increased water uptake and
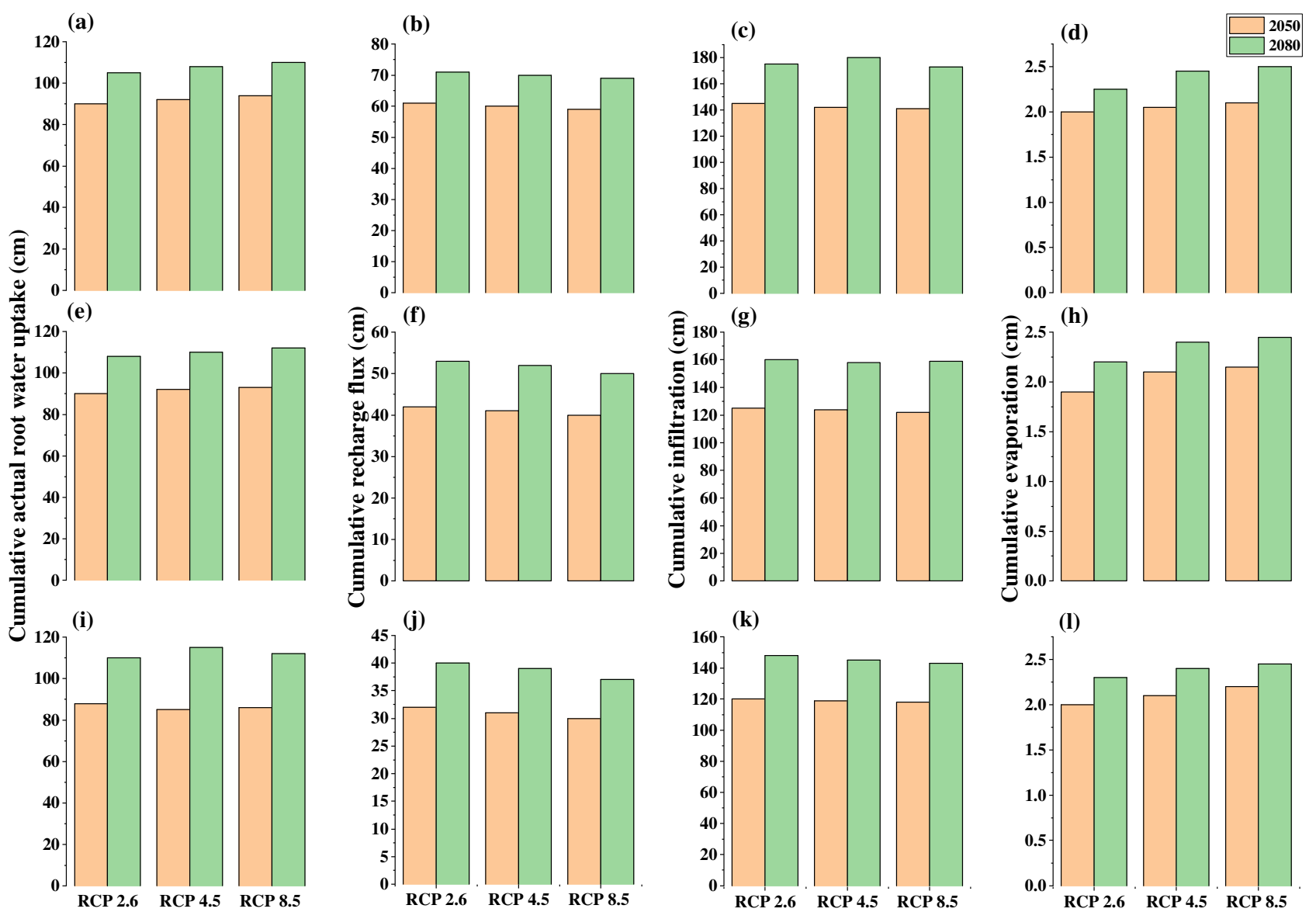

Figure 8: comparison of RCP 2.6, RCP 4.5, and RCP 8.5 for future (2021-2050 and 2051-2080) cumulative actual root water uptake $(\mathrm{cm})$, cumulative recharge fluxes $(\mathrm{cm})$, cumulative infiltration $(\mathrm{cm})$, and cumulative evaporation $(\mathrm{cm})$ under treatment $\mathrm{T}_{2}$ flat sowing (a-d), treatment $\mathrm{T}_{4}$ ridge sowing $(\mathrm{e}-\mathrm{h})$, and treatment $\mathrm{T}_{6}$ bed planting (i-1) method of irrigated cotton field without mulching practice. 
458 variable results are shown in Table 6. Results revealed that the model is only bound to elucidate

459 the variation groundwater recharge under cotton corps ranging from $23 \%(0.2378)$ in $\mathrm{T}_{6^{-}}$ RCP2.6_2050 to 5\% (0.512) case of T4-RCP4.5_2050. Correlation coefficient (r) results show 461 weak uphill linear relationships between groundwater recharge and climate variables. These 462 coefficients can quantify the real impact of climate variables in the changes in groundwater 463 recharge. Moreover, the sign of coefficients indicates that future climate changes would be 464 heterogeneous in the groundwater recharge versus climate variable. In the case of $\mathrm{T}_{2}-\mathrm{RCP} 4.5$, 465 climate variables account for only $23.11 \%$ of groundwater recharge flux, whereas $76.89 \%$ of the 466 variation in recharge flux could be explained by other influential factors (fate and transport of 467 solute, drainage practice, and soil texture along with soil organic matter). Recharge flux is 468 controlled by $1-4 \%$ of annual average rainfall (Sandoval et al. 2018). Likewise, the regression 469 analysis point to $\mathrm{R}^{2}$ (coefficient of determination) of 0.2109 , implying that the impact of climate 470 variables explains $21.09 \%$ of the recharge flux changes in $\mathrm{T}_{4}-\mathrm{RCP} 8.5$, while $78.91 \%$ controlled 471 by other factors such as flood and drought. Reinecke et al. (2020) reported that the uncertainty 472 range in climate change is large, and predictions with confidence with groundwater recharge can 473 only be made for a specific region.

Table 6: Multivariate regression analysis of groundwater recharge in terms of climate parameters

\begin{tabular}{|c|c|c|c|c|c|c|c|}
\hline \multirow{2}{*}{$\begin{array}{c}\text { Treatments \& } \\
\text { Scenarios }\end{array}$} & \multicolumn{5}{|c|}{ Coefficients } & \multirow{2}{*}{$\mathbf{r}$} & \multirow{2}{*}{$\mathbf{R}^{2}$} \\
\hline & $\mathbf{T}_{\max }$ & $\mathbf{T}_{\min }$ & $\mathbf{R}_{\mathbf{f}}$ & $\mathbf{R}_{\mathbf{H}}$ & $\mathbf{W}_{\mathbf{S}}$ & & \\
\hline T2- RCP2.6_2050 & -0.4724 & 0.2867 & 1.1948 & -0.0531 & -1.231 & 0.379 & 0.144 \\
\hline T4- RCP2.6_2050 & 0.1356 & -0.0758 & 0.3322 & 0.0258 & -0.0244 & 0.2403 & 0.0577 \\
\hline T6- RCP2.6_2050 & 0.2260 & -0.2 & 2.3135 & 0.0239 & 0.1416 & 0.4876 & 0.2378 \\
\hline$T_{2}-\mathbf{R C P 4 . 5} 2050$ & 0.0290 & -0.0605 & 2.7084 & 0.0572 & -1.0409 & 0.4807 & 0.2311 \\
\hline T4- RCP4.5_2050 & 0.0904 & -0.0931 & 0.2538 & 0.0071 & 0.0143 & 0.1455 & 0.0512 \\
\hline T6- RCP4.5_2050 & -0.1618 & -0.0066 & 0.7273 & -0.0542 & -0.3692 & 0.2691 & 0.0724 \\
\hline$T_{2}-$ RCP8.5_2050 & 0.5207 & -0.3450 & 0.6784 & 0.2086 & 0.7801 & 0.4579 & 0.2097 \\
\hline T4- RCP8.5_2050 & 0.1724 & -0.1463 & 0.4760 & 0.0267 & 0.1245 & 0.2822 & 0.0796 \\
\hline
\end{tabular}




\begin{tabular}{|c|c|c|c|c|c|c|c|}
\hline T6- RCP8.5_2050 & -0.0034 & -0.0028 & 1.3989 & -0.0115 & -0.1705 & 0.2346 & 0.0550 \\
\hline T2- RCP2.6_2080 & 0.5037 & -0.1978 & 1.1592 & -0.1776 & -0.0648 & 0.2101 & 0.0841 \\
\hline T4- RCP2.6_2080 & 0.0904 & -0.0931 & 0.2538 & 0.0071 & 0.0143 & 0.2777 & 0.0771 \\
\hline T6- RCP2.6_2080 & 0.0934 & -0.0069 & 0.1552 & 0.1214 & -0.0151 & 0.1484 & 0.0520 \\
\hline T2- RCP4.5_2080 & 0.3669 & -0.3275 & 1.5760 & 0.0468 & 1.0508 & 0.4046 & 0.1637 \\
\hline T4- RCP4.5_2080 & -0.7728 & 0.3510 & 0.4367 & -0.2107 & 0.5417 & 0.4057 & 0.1646 \\
\hline T6- RCP4.5_2080 & 0.0631 & -0.1600 & 0.3921 & -0.0546 & 0.6086 & 0.2951 & 0.0871 \\
\hline T2- RCP8.5_2080 & -0.0909 & 0.0510 & 2.1426 & 0.0417 & -1.1370 & 0.3936 & 0.1549 \\
\hline T4- RCP8.5_2080 & -0.5533 & 0.3666 & 0.7395 & -0.0521 & 0.0489 & 0.4592 & 0.2109 \\
\hline T6- RCP8.5_2080 & -0.3018 & 0.7681 & 0.1489 & -0.0330 & -0.6301 & 0.3887 & 0.1511 \\
\hline
\end{tabular}

(p>0.05; significant level 95\%)

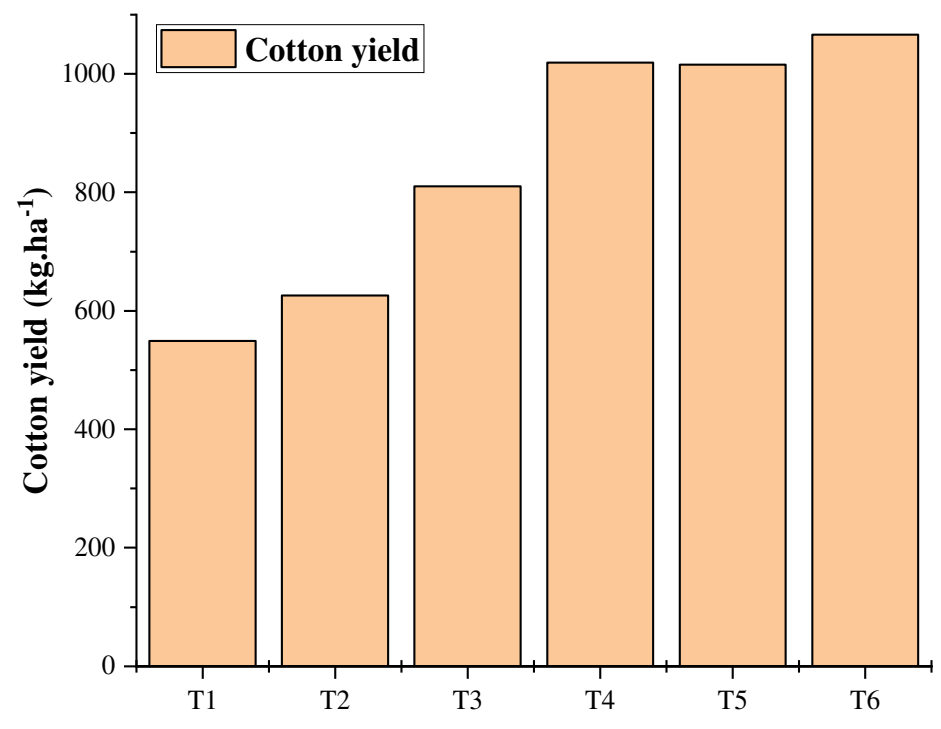

Treatments

476

477

478

479 irrigation requirement from 960.1 to $1048.9 \mathrm{~mm}$ in Pakistan (Arshad et al. 2019; Abbas 2020;

480

481

482

483 first, under-bed planting is less recharge flux and infiltration (Fig. 8j\&k) and more cotton yield. 484 Second, others without plastic mulch cotton have a greater yield than mulch. Therefore, existing
485 agronomical should be replaced by adopting bed planting and without mulch regardless of the 484 Second, others without plastic mulch cotton have a greater yield than mulch. Therefore, existing
485 agronomical should be replaced by adopting bed planting and without mulch regardless of the

Figure 9: cotton yield in terms of sowing methods and treatments

Climate change decreases cotton yield from 699 to $534 \mathrm{~kg} \cdot \mathrm{ha}^{-1}$ and elevates cotton Rehman 2021). However, from $\mathrm{T}_{1}$ to $\mathrm{T}_{6}$, cotton yield per hectare increased (Fig. 9). Bed planting without mulch $\left(\mathrm{T}_{6}\right)$ cotton sowing method has shown the highest cotton yield $\left(1066 \mathrm{~kg}\right.$. ha $\left.{ }^{-1}\right)$ followed by ridge planting without mulch $\left(\mathrm{T}_{4}, 1019 \mathrm{~kg}\right.$. ha $\left.{ }^{-1}\right)$. It elucidates two significant facts; 
cotton sowing method. As the future climate seems to get warmer, it needs to find such phenotypes variety of cotton crop that survive and yield good results under climate warming (high-yielded crop varieties are needed for a region with arid to semi-arid climate). Besides, it is equally important to adopt climate change adaptation measures for sustainable water resources management to avoid food security risks in the future.

Across Pakistan, groundwater contribution is estimated at $60 \%$ for agriculture, while $60 \%$ of irrigation water is lost due to poor infrastructure of conveyance and inadequate application in the field (Imran 2019). In Abu Dhabi (United Arab Emirates), 76\% of farmers rely on groundwater as a primary source with low water productivity (Al Tenaiji et al. 2021). Adopting climate-smart agriculture in water stress regions (arid and semi-arid) would combat climate change, water scarcity, and groundwater depletion that can enhanced cotton yield (90 kg.ha-1) (Jamil et al. 2021).

On the other hand, cotton farmers in Pakistan have a less yield and inefficient use of resources; thereby, irrigation water, soil, and agronomical management practices and technologies are economical, financially, and environmentally desirable for rural socio-economic development. Therefore, there is a need to develop and implement effective strategies to maintain groundwater and agricultural development sustainability.

\section{Conclusion}

Downscaling technique was used to calibrate and predict future climate parameters under climate change scenarios RCP 2.6, RCP 4.5, and RCP 8.5 for 2021-50 and 2051-80. That shows the gradual increase in maximum (minimum) temperature and decreased rainfall, relative humidity, and wind speed. Hydrus-1D unsaturated flow model was calibrated underlying the cotton crop with six different agronomical practices. Maximum cumulative recharge was occurred under $\mathrm{T}_{2}(75 \mathrm{~cm})$, followed by $\mathrm{T}_{4}(70 \mathrm{~cm})$, and actual root water uptake was highest under $\mathrm{T}_{6}(83$ 
cm). Cumulative recharge flux under climate change decreased for 2021-50 and 2051-80. The highest recharge was observed at $71 \mathrm{~cm}$ for 2051-80 under RCP $2.6\left(\mathrm{~T}_{2}\right)$. Multivariate regression analysis revealed that only $5-23 \%$ of groundwater recharge controlled by climate variables, has a weak (positive) relationship between groundwater recharge and climate variables. Bed planting without mulch $\left(\mathrm{T}_{6}\right)$ cotton sowing method has shown the highest cotton yield $\left(1066 \mathrm{~kg}^{\mathrm{h}} \mathrm{ha}^{-1}\right)$ and, under future climate changes, has less recharge flux and infiltration. Therefore, it is equally important to adopt climate change adaptation measures for sustainable water resources management to avoid food security risks in the future. It is recommended that the current agronomical practice of cotton sowing shall be replaced with bed planting, and mulching practice should be prohibited for greater cotton yield to achieve sustainable development.

\section{Declarations}

Ethical approval and consent to participate: Not applicable.

Consent to publication: The authors consent to publish current research in the ESPR journal.

Conflict of Interests: The authors have no conflict of interest.

Funding: Not applicable

Data availability and materials: Data are available upon request from the corresponding author.

Acknowledgment: Authors are thankful for the constructive comments to improve the manuscript to Mr. Farhan Saleem affiliated with the Institue of Atmospheric Physics, Chinese Academy of Science.

Authors contribution: Muhammad Saeed and Ahsan Maqbool designed, planned, conceptualized, conducted an experiment, data analysis and drafted the original manuscript, and Muhammad Adnan Ashraf was involved in the experiment, data acquisition, and statistical analysis, Muhammad Arshad, Kashif Mehmood, and Muhammad Usman were contributed to supervise, resources, editing the manuscript literature review, and proofreading and Muhammad Arslan Farid was involved in conducting an experiment, proofreading during the manuscript drafting stage.

\section{References}

Abbas S (2020) Climate change and cotton production: an empirical investigation of Pakistan. Environ Sci Pollut Res 27:29580-29588. https://doi.org/10.1007/s11356-020-09222-0 
sustainability for arid lands: the case of Abu Dhabi. Int J Water Resour Dev 37:584-602. https://doi.org/10.1080/07900627.2019.1654440

Amare G, Desta B (2021) Coloured plastic mulches: impact on soil properties and crop productivity. Chem Biol Technol Agric 8:4. https://doi.org/10.1186/s40538-020-00201-8

AMIS (2016) Agriculture Marketing Information Service. http://amis.pk/Agristatistics/DistrictWise/DistrictWiseData.aspx. Accessed 18 May 2018

Anderson MP, Woessner WW, Hunt RJ (2015) Spatial Discretization and Parameter Assignment. In: Applied Groundwater Modeling. Elsevier, pp 181-255

Arshad A, Zhang Z, Zhang W, Gujree I (2019) Long-Term Perspective Changes in Crop Irrigation Requirement Caused by Climate and Agriculture Land Use Changes in Rechna Doab, Pakistan. Water 11:1567. https://doi.org/10.3390/w11081567

Azam MI, Guo J, Shi X, et al (2020) Evaluation of statistical model for future precipitation and temperature in drainage area of Jhelum river, Pakistan. Pakistan J Agric Sci 57:605-613. https://doi.org/10.21162/PAKJAS/20.9645

Batalha MS, Barbosa MC, Faybishenko B, van Genuchten MT (2018) Effect of temporal averaging of meteorological data on predictions of groundwater recharge. J Hydrol Hydromechanics 66:143-152. https://doi.org/10.1515/johh-2017-0051

Bessah E, Boakye EA, Agodzo SK, et al (2021) Increased seasonal rainfall in the twenty-first century over Ghana and its potential implications for agriculture productivity. Environ Dev Sustain. https://doi.org/10.1007/s10668-020-01171-5

Bitterlich S, Durner W, Iden SC, Knabner P (2004) Inverse Estimation of the Unsaturated Soil Hydraulic Properties from Column Outflow Experiments Using Free-Form Parameterizations. Vadose Zo J. https://doi.org/10.2113/3.3.971

Boughanmi M, Dridi L, Hamdi M, et al (2018) Impact of floodwaters on vertical water fluxes in the deep vadose zone of an alluvial aquifer in a semi-arid region. Hydrol Sci J 63:136-153. https://doi.org/10.1080/02626667.2017.1410281 
Chaudhry QUZ (2017) Climate Change Profile of Pakistan. Manila, Philippines

Dahri ZH, Ludwig F, Moors E, et al (2021) Climate change and hydrological regime of the highaltitude Indus basin under extreme climate scenarios. Sci Total Environ 768:144467. https://doi.org/10.1016/j.scitotenv.2020.144467

Ficklin DL, Luedeling E, Zhang M (2010) Sensitivity of groundwater recharge under irrigated agriculture to changes in climate, $\mathrm{CO} 2$ concentrations and canopy structure. Agric Water Manag 97:1039-1050. https://doi.org/10.1016/j.agwat.2010.02.009

Gebrechorkos SH, Hülsmann S, Bernhofer C (2019) Statistically downscaled climate dataset for East Africa. Sci Data 6:31. https://doi.org/10.1038/s41597-019-0038-1

Hoar T, Nychka D (2008) Statistical downscaling of the community climate system model (CCSM) monthly temperature and precipitation projections. Boulder

Huang H, Han Y, Jia D (2019) Impact of climate change on the blue water footprint of agriculture on a regional scale. Water Supply 19:52-59. https://doi.org/10.2166/ws.2018.046

Hussain N, Anwar A, Yasmeen A, et al (2021) Resource use efficiency of cotton in improved vs conventional planting geometry with exogenous application of bio-stimulant and synthetic growth retardant. Brazilian J Biol 81:18-26. https://doi.org/10.1590/1519-6984.213951

Imran M (2019) Pakistan's ground water level falling a meter every year. News

Jamil I, Jun W, Mughal B, et al (2021) Does the adaptation of climate-smart agricultural practices increase farmers' resilience to climate change? Environ Sci Pollut Res 28:2723827249. https://doi.org/10.1007/s11356-021-12425-8

Jin X, Chen M, Fan Y, et al (2018) Effects of Mulched Drip Irrigation on Soil Moisture and Groundwater Recharge in the Xiliao River Plain, China. Water 10:1755. https://doi.org/10.3390/w10121755

Kambale JB, Singh DK, Sarangi A (2017) Impact of climate change on groundwater recharge in 
Kazmi DH, Li J, Ruan C, et al (2016) A statistical downscaling model for summer rainfall over Pakistan. Clim Dyn 47:2653-2666. https://doi.org/10.1007/s00382-016-2990-1

Kelleners TJ, Beekma J, Chaudhry MR (1999) Spatially variable soil hydraulic properties for simulation of field-scale solute transport in the unsaturated zone. Geoderma. https://doi.org/10.1016/S0016-7061(99)00032-4

Khaliq A, Maqbool A, Tansar H, et al (2021) Groundwater pumping modeling for the sustainable management of urban water supply in Faisalabad city, Pakistan. Arab J Geosci 14:442. https://doi.org/10.1007/s12517-021-06499-4

Khan F, Ali S, Pilz J (2018) Evaluation of statistical downscaling models using pattern and dependence structure in the monsoon-dominated region of Pakistan. Weather 73:193-203. https://doi.org/10.1002/wea.3164

Khan HF, Yang YCE, Ringler C, et al (2017) Guiding Groundwater Policy in the Indus Basin of Pakistan Using a Physically Based Groundwater Model. J Water Resour Plan Manag 143:. https://doi.org/10.1061/(ASCE)WR.1943-5452.0000733

Kobuliev M, Liu T, Kobuliev Z, et al (2021) Effect of future climate change on the water footprint of major crops in southern Tajikistan. Reg Sustain 2:60-72. https://doi.org/10.1016/j.regsus.2021.01.004

Laflamme EM, Linder E, Pan Y (2015) Statistical downscaling of regional climate model output to achieve projections of precipitation extremes. Weather Clim Extrem 12:15-23. https://doi.org/10.1016/j.wace.2015.12.001

Lv G, Hu W, Kang Y, et al (2013) Root Water Uptake Model Considering Soil Temperature. J Hydrol Eng 18:394-400. https://doi.org/10.1061/(asce)he.1943-5584.0000642

Maqbool A, Ashraf MA, Khaliq A, et al (2021) Efficient water allocation strategy to overcoming water inequity crisis for sustainability of agricultural land: a case of Southern Punjab, 
Mualem Y (1976) A new model for predicting the hydraulic conductivity of unsaturated porous media. Water Resour Res 12:513-522. https://doi.org/10.1029/WR012i003p00513

Naheed G, Rasul G (2005) Recent Water Requirement of Cotton Crop in Pakistan. Pakistan J Meteorol 6:75-84

Pomee MS, Ashfaq M, Ahmad B, Hertig E (2020) Modeling regional precipitation over the Indus River basin of Pakistan using statistical downscaling. Theor Appl Climatol 142:29_ 57. https://doi.org/10.1007/s00704-020-03246-9

Pool S, Francés F, Garcia-Prats A, et al (2021) From Flood to Drip Irrigation Under Climate Change: Impacts on Evapotranspiration and Groundwater Recharge in the Mediterranean Region of Valencia (Spain). Earth's Futur 9:1-20. https://doi.org/10.1029/2020EF001859

Qi Y, Yang X, Huerta-Lwanga E, et al (2020) Microplastics in the agroecosystem : effects of plastic mulch film residues on the soil-plant system. $\mathrm{PhD}$ thesis, Wageningen University. In: EGU General Assembly 2020. p 13733

Rahman M, Rosolem R, Kollet SJ, Wagener T (2019) Towards a computationally efficient freesurface groundwater flow boundary condition for large-scale hydrological modelling. Adv Water Resour 123:225-233. https://doi.org/10.1016/J.ADVWATRES.2018.11.015

Rehman S (2021) Cotton and Products Annual. Islamabad

Reinecke R, Müller Schmied H, Doell P (2020) Changes of groundwater recharge at different global warming levels: A global-scale multi-model ensemble approach

Resende NC, Miranda JH, Cooke R, et al (2019) Impacts of regional climate change on the runoff and root water uptake in corn crops in Parana, Brazil. Agric Water Manag 221:556565. https://doi.org/10.1016/j.agwat.2019.05.018

Rodríguez-Huerta E, Rosas-Casals M, Hernández-Terrones LM (2020) A water balance model to 

estimate climate change impact on groundwater recharge in Yucatan Peninsula, Mexico. Hydrol Sci J 65:470-486. https://doi.org/10.1080/02626667.2019.1702989

Saddique N, Khaliq A, Bernhofer C (2020) Trends in temperature and precipitation extremes in historical (1961-1990) and projected (2061-2090) periods in a data scarce mountain basin, northern Pakistan. Stoch Environ Res Risk Assess 34:1441-1455. https://doi.org/10.1007/s00477-020-01829-6

Saleem F, Zeng X, Hina S, Omer A (2021) Regional changes in extreme temperature records over Pakistan and their relation to Pacific variability. Atmos Res 250:105407. https://doi.org/10.1016/j.atmosres.2020.105407

Sandoval E, Baldo G, Núñez J, et al (2018) Groundwater recharge assessment in a rural, arid, mid-mountain basin in North-Central Chile. Hydrol Sci J 63:1873-1889. https://doi.org/10.1080/02626667.2018.1545095

Şen Z (2015) Climate Change, Droughts, and Water Resources. In: Applied Drought Modeling, Prediction, and Mitigation. Elsevier, pp 321-391

Siad SM, Iacobellis V, Zdruli P, et al (2019) A review of coupled hydrologic and crop growth models. Agric Water Manag 224:105746. https://doi.org/10.1016/j.agwat.2019.105746

Šimůnek J, M. Šejna A, Saito H, et al (2013) The HYDRUS-1D software package for simulating the movement of water, heat, and multiple solutes in variably saturated media, version 4.17. HYDRUS Softw Ser 3D 343

Tenreiro TR, García-Vila M, Gómez JA, et al (2020) Water modelling approaches and opportunities to simulate spatial water variations at crop field level. Agric Water Manag 240:106254. https://doi.org/10.1016/j.agwat.2020.106254

Turkeltaub T, Dahan O, Kurtzman D (2014) Investigation of Groundwater Recharge under Agricultural Fields Using Transient Deep Vadose Zone Data. Vadose Zo J 13:vzj2013.10.0176. https://doi.org/10.2136/vzj2013.10.0176

van Genuchten MT (1980) A Closed-form Equation for Predicting the Hydraulic Conductivity of 
Unsaturated Soils. Soil Sci Soc Am J.

https://doi.org/10.2136/sssaj1980.03615995004400050002x

van Genuchten MT (1987) A numerical model for water and solute movement in and below the root zone

Van Looy K, Bouma J, Herbst M, et al (2017) Pedotransfer Functions in Earth System Science: Challenges and Perspectives. Rev Geophys 55:1199-1256. https://doi.org/10.1002/2017RG000581

Vinca A, Parkinson S, Riahi K, et al (2020) Transboundary cooperation a potential route to sustainable development in the Indus basin. Nat Sustain 4:331-339. https://doi.org/10.1038/s41893-020-00654-7

Wakode HB, Baier K, Jha R, Azzam R (2018) Impact of urbanization on groundwater recharge and urban water balance for the city of Hyderabad, India. Int Soil Water Conserv Res 6:5162. https://doi.org/10.1016/j.iswcr.2017.10.003

Wang L, Guo R, Wumaierjian K, et al (2020) Effects of subsoiling depth on water use efficiency and yield of cotton field under drip irrigation in south Xinjiang, China (In Chinese). Trans Chinese Soc Agric Eng 36:144-152

Wu W-Y, Lo M-H, Wada Y, et al (2020) Divergent effects of climate change on future groundwater availability in key mid-latitude aquifers. Nat Commun 11:3710. https://doi.org/10.1038/s41467-020-17581-y

Xi B, Bloomberg M, Watt MS, et al (2016) Modeling growth response to soil water availability simulated by HYDRUS for a mature triploid Populus tomentosa plantation located on the North China Plain. Agric Water Manag 176:243-254. https://doi.org/10.1016/j.agwat.2016.06.017

Xu M, Li C (2020) The Concepts of Virtual Water and Water Footprint. In: Application of the Water Footprint: Water Stress Analysis and Allocation. Springer Singapore, Singapore, pp $9-16$ 
691 